\title{
Climate impacts on the landings of Indian oil sardine over the south-eastern Arabian Sea
}

\author{
Faseela Hamza $^{1}$ (D) | Vinu Valsala ${ }^{1}$ | Anju Mallissery ${ }^{1,2}$ | Grinson George ${ }^{3}$
}

${ }^{1}$ Indian Institute of Tropical Meteorology, Ministry of Earth Sciences, Pune, India

${ }^{2}$ Department of Meteorology and Oceanography, College of Science and Technology, Andhra University, Vishakhapatnam, India

${ }^{3}$ Central Marine Fisheries Research Institute, Kochi, India

\section{Correspondence}

Faseela Hamza, Indian Institute of Tropical Meteorology, Ministry of Earth Sciences, Pune, India.

Email: faseela@tropmet.res.in

\begin{abstract}
The landings of Indian oil sardine (Sardinella longiceps, Clupeidae) along the southeastern Arabian Sea are about $43.8 \%$ of total Indian oil sardine production. The annual landings of this species exhibit large-scale variability with prolonged years of surplus or deficit landings without identified reason. Evaluating Indian oil sardine landings along the Kerala coast during 1961-2017 in relation to environmental variations, we have elucidated a putative link between variability in landings versus environmental parameters and climate indices. The variables examined in this study, such as salinity and temperature along with physical indices such as upwelling and mixed layer depth (MLD) of the ocean help to propose a mechanism to temporal variability in the landings of Indian oil sardine. Colder temperature and timely intense upwelling lead to nutrient enrichment in the surface water, which promotes the growth of phytoplankton (chl-a) and thereby food availability to Indian oil sardine are found during years with surplus catch. Less saline surface waters and shoaling of MLD at these times could lead to the aggregation of fish at particular depths and thereby a good catches. The reverse mechanism, such as more surface saline water, warm temperature, downwelling or weak upwelling, and less nutrient enrichment, leads to deficit landings. Further, it was noticed that the Pacific decadal oscillation and Atlantic multidecadal oscillation have a more pronounced impact on Indian oil sardine landings over the coast of south-eastern Arabian Sea than previously reported ENSO associated impacts. All these point towards climate change implications for the Indian oil sardine fishery.
\end{abstract}

\section{KEYWORDS}

Atlantic multidecadal oscillation, chlorophyll- $a$, mixed layer depth, ocean temperature, Pacific decadal oscillation, upwelling

\section{1 | INTRODUCTION}

The south-west coast of peninsular India is one of the prominent upwelling regions in the Indian Ocean. Approximately $30 \%$ of the marine fish production of the nation comes from this upwelling ecosystem (Bakun et al., 1998; Krishnakumar \& Bhat, 2008; Manjusha et al., 2013), which is known to have a variety of small pelagics including Indian oil sardine (Sardinella longiceps, Clupeidae). This species is the single largest contributor $(\sim 10 \%)$ to the total marine fish production of India. Out of this, 45\% comes from the Kerala coast (a part of the south-west coast of peninsular India; CMFRI, 2018). Indian oil sardine is widely used as aquaculture feed, for preparation of the fish meal, industrial oil and health supplements in addition to direct human consumption (Alder et al., 2008; Barange et al., 2014). It is of increasing interest for conservation also, as this species is a critical forage for marine predators including fish, mammals and seabirds and thus it provides a key linkage from lower trophic to 
upper trophic levels (Cury et al., 2011; Fréon et al., 2005; Pikitch et al., 2014).

Globally, the sardine fishery has shown wide fluctuations during the past 100 years, that is with relatively high abundance during some years and scarce during other years, in addition to their spatial variability (Guiñez et al., 2014; Izquierdo-Peña et al., 2019; Ma et al., 2019; Schwartzlose \& Alheit, 1999). The fisheries of sardines and anchovies across the coast of California, Peru, South Africa and Japan have displayed wide spatio-temporal fluctuations (Barange et al., 2009; Chavez et al., 2003; Cheung et al., 2010; Oozeki et al., 2019). Similarly, the landings of Indian oil sardine from Kerala also exhibit considerable temporal variations (Kripa et al., 2018; Krishnakumar et al., 2008).

Marine fish production naturally exhibits large temporal fluctuations which are usually attributed to the exploitation patterns (Essington et al., 2015). The fluctuations in the abundance of small pelagics have been observed even decades before the development of mechanization and preservation techniques (Krishnakumar et al., 2008; Lluch-Belda et al., 1989). Therefore, these fluctuations could also help reveal the influence of environmental factors and their corresponding variability in the landings of pelagics, especially for the sardines and anchovies (Checkley et al., 2009; Lluch-Belda et al., 1989; Lindegren et al., 2013). Global fluctuations in the production of sardines and anchovies seem to be controlled by longterm variations in environmental parameters, resulting in "regimes" in their fishery in a particular spatio-temporal domain (Blanchard et al., 2012; Checkley Jr et al., 2017; Izquierdo-Peña et al., 2019). This relation has been widely studied in the Northeast Atlantic, Mediterranean Sea, China Seas and Pacific coasts and recently reported as a collection of papers in a special issue of the Deep Sea Research-II (Alheit et al., 2019). However, similar studies on Indian oil sardine and other small pelagics from the Indian coastal waters are limited. The existing studies have focused on short-term variability of a few selected environmental parameters and for a limited time (Jayaprakash, 2002; Kripa et al., 2018; Krishnakumar et al., 2008; Longhurst \& Wooster, 1990; Menon et al., 2019; Xu \& Boyce, 2009).

The Indian oil sardine is a clupeid fish with a limited spatial distribution in the tropical waters of the northern and western Arabian Sea. The annual production of oil sardine is determined by the active spawning and efficient recruitment of juveniles. Both depend on the various favourable environmental parameters (Kripa et al., 2018). Among these, the availability of food, salinity, temperature, upwelling and mixed layer depth is found to be most important (Harrison \& Chiodi, 2015; Joseph \& Jayaprakash, 2003; Menon et al., 2019). Temperature influences the growth and sexual maturation of oil sardine (Kizhakudan et al., 2014). The optimum temperature for an abundant fishery ranges between 27 and $28^{\circ} \mathrm{C}$ (Bensam, 1970). Reduced salinity (below 34 p.s.u) and thermal stratification conditions cause physiological stress in the organism (Jurado-Ruzafa et al., 2019; MacKenzie et al., 2000). On the other hand, mixing and upwelling enhance the availability of food and favourable spawning grounds for oil sardines (Manjusha et al., 2013; Rykaczewski \& Checkley, 2008). The availability of food during the early life

\begin{tabular}{|c|c|}
\hline 1 INTRODUCTION & 175 \\
\hline 2 DATA AND METHODS & 177 \\
\hline 2.1 Data & 177 \\
\hline 2.2 Methodology & 177 \\
\hline $\begin{array}{l}2.3 \text { Spectral decomposition of landings into short- } \\
\text { and long-term variability }\end{array}$ & 178 \\
\hline 3 RESULTS & 178 \\
\hline $\begin{array}{l}\text { 3.1 Variability in landings of Indian oil sardine } \\
\text { along the south-eastern Arabian Sea }\end{array}$ & 178 \\
\hline $\begin{array}{l}\text { 3.2 Impact of food availability on the abundance } \\
\text { of Indian oil sardine }\end{array}$ & 179 \\
\hline $\begin{array}{l}\text { 3.3 Impact of environmental parameters on Indian } \\
\text { oil sardine landings }\end{array}$ & 181 \\
\hline 3.3.1 Effects of salinity & 181 \\
\hline 3.3.2 Effects of temperature & 182 \\
\hline 3.3.3 Coastal upwelling & 182 \\
\hline 3.3.4 Ocean mixed layer depth & 182 \\
\hline $\begin{array}{l}\text { 3.4 Long- and short-term variability of } \\
\text { environmental parameters and impact on Indian } \\
\text { oil sardine landings }\end{array}$ & 183 \\
\hline 3.4.1 Salinity & 183 \\
\hline 3.4.2 Temperature & 183 \\
\hline $\begin{array}{l}\text { 3.5 Connection of climatological indices to annual } \\
\text { landings of Indian oil sardine }\end{array}$ & 184 \\
\hline 4 DISCUSSION & 185 \\
\hline 5 CONCLUSIONS & 190 \\
\hline Acknowledgements & 190 \\
\hline Data Availability Statement & 190 \\
\hline REFERENCES & 190 \\
\hline
\end{tabular}

history stages plays a vital role in recruitment success (Van Poorten et al., 2018). Environmental factors also determine the distribution and drift of reproductive products, thereby the growth and survival of the juveniles (Longhurst, 2002; Zimmermann et al., 2018). Large-scale oceanographic processes and climatic oscillations are considered to act as the significant forcing factors responsible for the variability of the environmental parameters (Trenkel et al., 2014; Zimmermann et al., 2018). The combination and synchrony of various oceanographic processes and climatic oscillations affect the marine ecosystem and result in variabilities of the small pelagics populations (Alheit et al., 2019).

The relationship between large-scale climate induced variability in environmental parameters and the small pelagic population has not been studied in the south-eastern Arabian Sea (SEAS). Therefore, in the current study, we set our goal to examine the variability and trends of Indian oil sardine production (i.e. landings data of 1961-2017 along the Kerala coast) and its relation to different environmental parameters such as availability of food (phytoplankton observed as chlorophyll-a concentration), salinity, temperature, 
wind stress curl (as a measure of upwelling) and mixed layer depth (MLD) of the coastal waters of SEAS. Further, the study examines possible teleconnection relationships between the landings variability and the climate indices such as Pacific decadal oscillation (PDO), Atlantic multidecadal oscillation (AMO), North Atlantic oscillations (NAO), El Niño-Southern oscillation (ENSO) and Arctic oscillation $(A O)$.

\section{DATA AND METHODS}

\section{1 | Data}

We used annual landings data of Indian oil sardine along the Kerala coast for a period of 57 years from 1961 to 2017. These data were compiled from a published article (Kripa et al., 2018) and the annual reports of the Central Marine Fisheries Research Institute (CMFRI, http://eprints.cmfri.org.in/). For calculating catch per unit effort (CPUE), gear-wise oil sardine landings data along with gear-wise effort in unit operation from 1985 to 2016 is used, since the data are available only during this period. The CPUE data are prepared by considering different combinations of craft and gear such as fishing boats with out-board engines (ring seines, gill nets and boat seines), mechanized units (ring seines and trawlers) and other motorized units which are used for sardine fishing. The changes in fishing fleets are addressed while preparing the data. The data collected during closed seasons to monitor the landings happening in artisanal, motorized or other subsistence fishing methods were also incorporated in the CPUE data (Akash, 2018). For studying the variabilities of other pelagics, annual landings data along the Indian coast were collected from the website of CMFRI (www.cmfri.org.in/annual-data/).

Satellite-derived monthly chlorophyll-a (chl-a), a proxy of phytoplankton production (the availability of food to Indian oil sardine) is used from 1998 to 2016 (based on the availability of data). This data product is a merged surface chl- $a$ data at a spatial resolution of 4-km $\times 4-\mathrm{km}$ created by band-shifting and bias-correcting ocean colour data from MERIS, MODIS and VIIRS imagery and matching them to SeaWiFS data, (version 3.1 available at http://data.ceda.ac.uk/ neodc/esacci; Menon et al., 2019; Sathyendranath et al., 2018). The annual data of chl- $a$ were constructed by averaging the monthly values to explain the spatial climatological patterns.

Monthly ocean temperature and salinity data (EN.4.2.1) were taken from the Hadley Centre, MetOffice, UK (Good et al., 2013) with a vertical resolution of $10 \mathrm{~m}$ and at a horizontal resolution of $1^{\circ}$ latitude $\times 1^{\circ}$ longitude grid for the period from 1951 to 2017, obtained from http://www.metoffice.gov.uk/hadobs/en4. Simple Ocean Data Assimilation (SODA) monthly mixed layer depth (MLD) data (http:// apdrc.soest.hawaii.edu/data/data.php, Carton et al., 2000) was used at a resolution of $0.5^{\circ}$ latitude $\times 0.5^{\circ}$ longitude grid for the period from 1980-2015.

We have used monthly means of zonal and meridional winds at $10 \mathrm{~m}$ above mean sea level (u10 and v10) from the ERA-Interim reanalysis data for the computation of curl of surface wind stress. The
ERA-Interim reanalysis is a global atmospheric reanalysis product issued by the European Centre for Medium-Range Weather Forecasts (ECMWF), spanning from 1979 to the present. For the present study, we used data from 1979 to 2017 for the consistency in the analysis period with other parameters. The surface winds used are at a spatial resolution of $0.25^{\circ}$ latitude $\times 0.25^{\circ}$ longitude grid (Dee et al., 2011; Uppala et al., 2005).

In addition to the environmental parameters, we also used climate indices to explore the relationship between climate variability and annual fish landings. The indices used are PDO, AMO, NAO, ENSO and AO. The PDO is a recurring pattern of atmospheric-oceanic climate variability centred over north mid-latitude Pacific with SST anomalies of cold or warm phase for several decades (Mantua \& Hare, 2002). The AMO is defined as the 10 -year running mean of detrended North Atlantic SST anomalies, which swings between warm and cold phases. The approximate periodicity of this oscillation is about 60-80 years based on instrumental records (Knight et al., 2006). However, warm and cold phases in the AMO last for 20-40 years (Alexander et al., 2014), and these phases will influence the environmental parameters at those time scales (20-40 years). Moreover, in the mid-1990s, regime shifts in the marine ecosystem, indicated by the changes in the population of small pelagic fishes, have been noted in the eastern North and Central Atlantic concerning the AMO period (Alheit et al., 2014).

The NAO is a prominent atmospheric circulation variability centred over the North Atlantic, which modulates the strength of westerlies (Stenseth et al., 2003). The ENSO is centred in the oceanatmosphere circulations of the equatorial Pacific Ocean, operates on interannual time scales, and is an important source of interannual global climate change (Neelin et al., 1998). The AO is a large-scale pattern of variability in the atmospheric pressure centred in the Arctic and North Atlantic Ocean with positive and negative phases (Thompson \& Wallace, 2000). All these indices are downloaded from https://www.esrl.noaa.gov/psd (Nair et al., 2018). These climate forcings have teleconnections across vast distances around the globe. Therefore, we include them in the analysis to see whether they have any relation to the variability in landings of Indian oil sardine in our study area.

\section{2 | Methodology}

The fish landings data from 1961 to 2017 have been classified as surplus and deficit years of sardine landings based on their departure from the mean. If the departure is above $25 \%$ of the long-term mean, the year is considered as a surplus year. Similarly, if the departure is below $-25 \%$ of the long-term mean, the year is considered as a deficit year. These years are used for further analysis to understand the impact of various environmental parameters on sardine landings.

Additionally, we have analysed the standardized CPUE data to explore the role of fishing efforts in modulating the landings variability during the period 1985-2016. For calculating the standardized CPUE, gear-wise oil sardine landings data along with gear-wise 
effort in unit operation is used. The fishing effort is calculated based on the number of unit operations by various craft and gear combinations and the fishing hours spend by each unit. Multigear mean standardization methodology was used to standardize the CPUE data (Gibson-Reinemer et al., 2016). The CPUE $\left(c_{i j}\right)$, with $i$ species (in this case, Indian oil sardine) and $j$ observation, was calculated as $c_{i j}=\mathrm{TC}_{i j} / e$, where, $\mathrm{TC}_{i j}$ - is the total catch, and $e$ is the effort of the gear. The mean standardized CPUE (MSC ${ }_{i j}$ ) was estimated based on the relation $\mathrm{MSC}_{i j}=\left(c_{i j} / e\right) /(\mathrm{TC} / e)$, where $\mathrm{TC}$ is the mean of the total catch (Akash, 2018).

The effects of salinity and temperature (over the water column from surface to $30 \mathrm{~m}$ depth) on the landings of Indian oil sardine were analysed for surplus and deficit years during different seasons such as winter (January and February), pre-monsoon (March, April and May), monsoon (June, July, August and September) and post-monsoon (October, November and December) seasons. The roles of MLD and upwelling were analysed bimonthly for a better interpretation primarily related to sexual maturity, spawning and recruitment period. We considered the bimonthly periods as April-May, June-July, August-September and OctoberNovember, which are important periods related to biological and fishing activities.

The surface wind stress curl is used as a measure of upwelling (Castelao \& Barth, 2006). The bulk formula is used to estimate surface wind stress $(\tau)$ as,

$$
|\tau|=\rho C_{d}|\mathrm{~V}| \mathbf{V}
$$

where, $\rho$ is the density of air $\left(1.225 \mathrm{~kg} / \mathrm{m}^{3}\right), C_{d}$ is the drag coefficient (0.0013), and $V$ is the wind velocity (see Section 2.1).

The equation of wind stress curl is:

$$
\text { Curl }=\frac{\nabla \tau_{x}}{\nabla y}-\frac{\nabla \tau_{y}}{\nabla x}
$$

where $\tau_{x}$ and $\tau_{y}$ are the zonal and meridional components of wind stress, respectively. Further correlations between various climate indices and annual landings of Indian oil sardine were used to delineate the relationship between climate variability and Indian oil sardine landings variability. The inter-relationship and co-variability among the environmental parameters and annual landings data were calculated to understand their mutual dependency. The significance of the correlation coefficient was estimated based on the Student $t$ test.

\subsection{Spectral decomposition of landings into short- and long-term variability}

The ENSO index is expected to be more significant in the short-term time scale because it has a periodicity of 2-7 years (Cane, 2005). On the other hand, the indices such as PDO and AMO have the periodicities in the decadal time scale, and therefore, they are expected to have more influence on the long-term fluctuation of sardine landings. Therefore, the annual landings of Indian oil sardine in the SEAS for the study period have been spectrally decomposed in order to separate the landings with variabilities of 11 years and above (long cycle as CASE-1) and 10 years and below (short cycle as CASE-2). To separate the total variability of landings data into long and short cycles, we have done a Fourier transform (FT) harmonic analysis. Firstly, the time series of landings data is decomposed into its frequency and power spectrum using FT. Further, the time series of the short cycle is reconstructed using the powers of those frequencies ranging between $1 / 2$ and $1 / 10$ year $^{-1}$. Therefore, this short cycle embedded only the variabilities of 10 years and less. Similarly, we also reconstructed a long cycle with the variabilities of 11 years and longer (Wilks, 2011). The CASE-1 and CASE-2 data series were further used to identify surplus and deficit years in respective cases to understand the relative influences of the environmental parameters on their long- and short-term fluctuations. Here also, we categorized data into surplus and deficit years based on above and below $25 \%$ of the long-term mean of CASE-1 and CASE-2. We repeated the spatial features of temperature, salinity, upwelling and MLD for surplus and deficit years identified from CASE-1 and CASE-2 in order to explore the features during the long-term and short-term fluctuations, respectively.

\section{3 | RESULTS}

\subsection{Variability in landings of Indian oil sardine along the south-eastern Arabian Sea}

Wide fluctuations were observed in the landings of Indian oil sardine with an increasing trend of approximately 1 kilo tonne per year (Figure 1a), which is likely due to improved fishing effort, increasing demand and modern post-harvest handling techniques. The mean landings were around 150 kilo tonnes for the last 57 years, with a standard deviation of 80 kilo tonnes. Figure $1 \mathrm{~b}$ shows the detrended landings data with the long-term mean removed and representing the quantity as percentage of deviations from the long-term mean. The landings of Indian oil sardine exhibited large interannual variability with prolonged surplus or deficit years of catch spanning several decades. It is striking that the magnitude of the variability is lower in the early decades; however, it gradually increased in the recent decades. The landings declined up to 60 and 40 kilo tonnes in 1963 and 1986, respectively, with a record low of 1.5 kilo tonnes in 1994. During the early decades, the highest landings in these decades were observed in the year 1968 with 250 kilo tonnes of catch with an all-time peak of 400 kilo tonnes was observed in 2012. A declining trend is registered in the recent decades starting from 2015, and the same could be expected for forthcoming years if the same decadal variability pattern is followed. For further analysis, we categorized the surplus and deficit years of landings, as explained in the methodology section. 
FIGURE 1 Landing variability of Indian oil sardine over the south-eastern Arabian coast during 1961 to 2017 (a) interannual variability and linear trend based on the regression fit (the slope of the fit is 989.6 tonnes per year) (b) percentage deviations of detrended long-term mean along with the 11-year running mean (solid line) to explain the decadal variability of Indian oil sardine
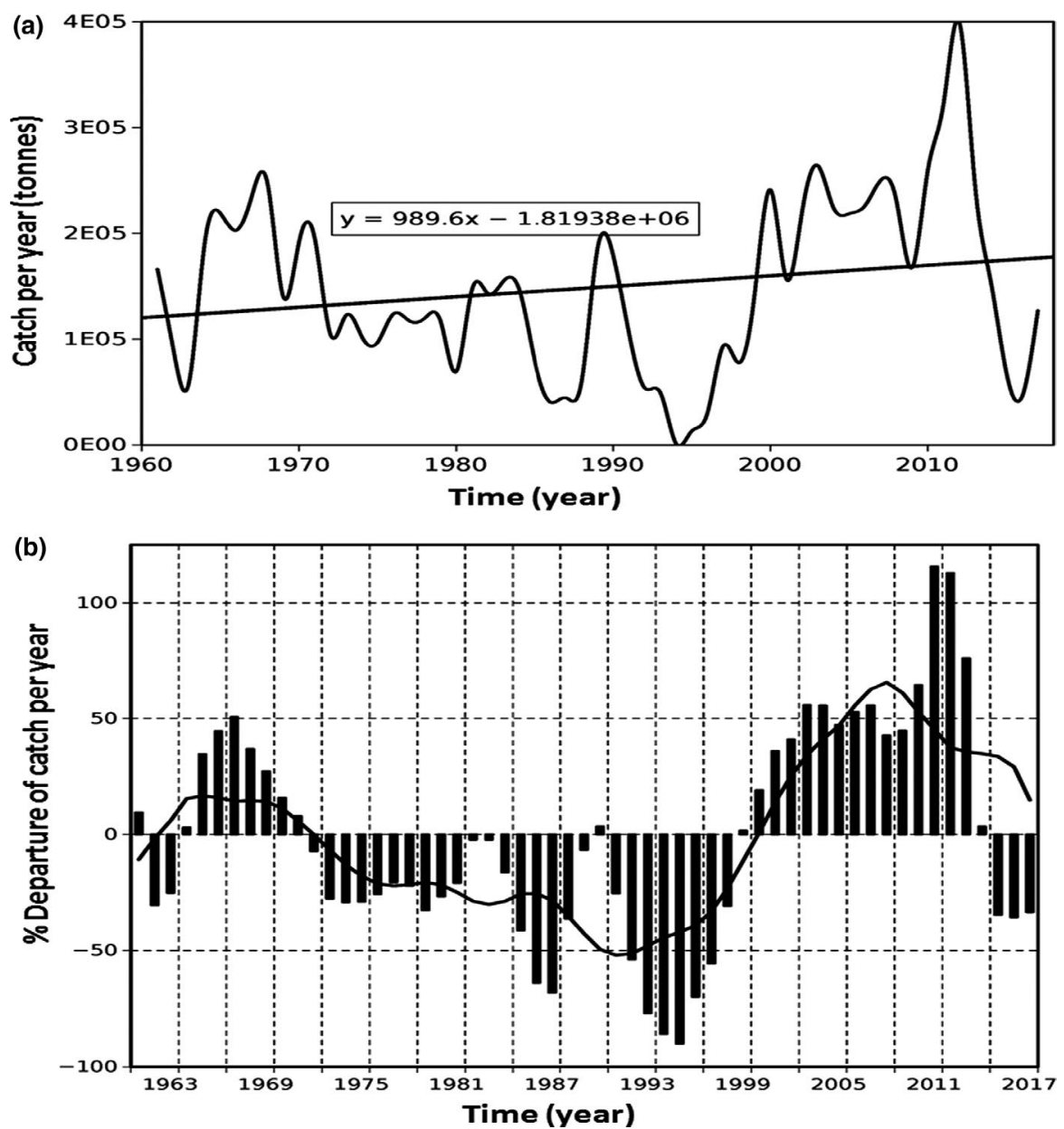

In addition to the landings data, we also used the standardized CPUE for 30-year period to explore the modulation of landings variability due to the fishing efforts by various fishing craft and gear combinations (Figure 2a). Further, we identified surplus and deficit years from the standardized CPUE data sets. We found that these years match with the surplus and deficit years identified from annual landings data, except for three random years in both surplus and deficit cases (Figure $2 b$ ). The temporal variability of both the data sets was also similar, with a linear correlation coefficient of 0.8 , which has a confidence level at more than $99 \%$, based on the Student $t$ test. Therefore, for further analysis of various environmental parameters, the surplus and deficit years derived from the annual landings data was used. It is re-stated that there are no changes in the results of the analysis, whether we exclude or include the missing three years of standardized CPUE data sets in the analysis. The oil sardine landings data and the environmental parameters were subjected to covariance and correlation analysis to identify inter-relationships among parameters. In general, the values of covariance and correlation are in the same direction as the in-phase changes in magnitude (Table 1). The catch shows in-phase variability with chl-a, salinity and wind stress curl. The temperature and MLD shows a significant negative correlation with annual landings data at $10 \%$ and $1 \%$ significance levels, respectively. Similarly, the values of normalized covariance also show strong positive values when the correlation values are significant. Food availability has a negative relation with all other environmental parameters, as evidenced by the negative correlation values. Among the values of matrix, the temperature shows a significant inverse correlation (at 10\% level) with food availability and positive correlation (at 5\% levels) with MLD. Similarly, salinity shows an in-phase relationship with wind stress curl, and this relationship is significant at the $10 \%$ level.

\subsection{Impact of food availability on the abundance of Indian oil sardine}

Indian oil sardine is a phytoplankton feeder, with a preference for diatoms (Rohit et al., 2018). The presence of chl- $a$ in the study area was examined, and it was found more concentrated in the nearshore area (fishing zone of Indian oil sardine) during the surplus years (Figure 3a). On the other hand, this pigment was found to be dispersed with less concentration in the nearshore area during the deficit years (Figure $3 \mathrm{~b}$ ). The difference in the concentration of chl-a during the surplus and deficit years is given in Figure 3c. It is found that the chl- $a$ is more 


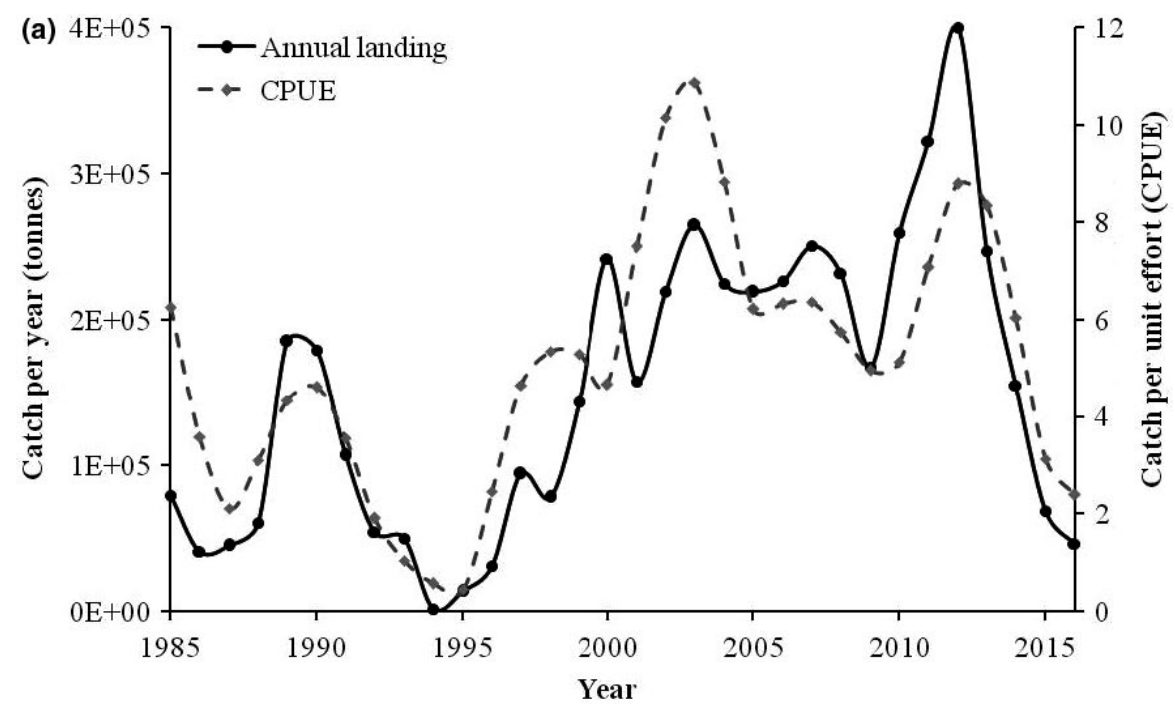

FIGURE 2 Comparison between landing variability and Catch per unit effort (CPUE) of Indian oil sardine along the coast of south-eastern Arabian Sea during 1985 to 2016 (a) interannual variability of annual landings and CPUE (b) percentage deviation of annual landing data (black bars) and CPUE (grey bars) from long-term mean

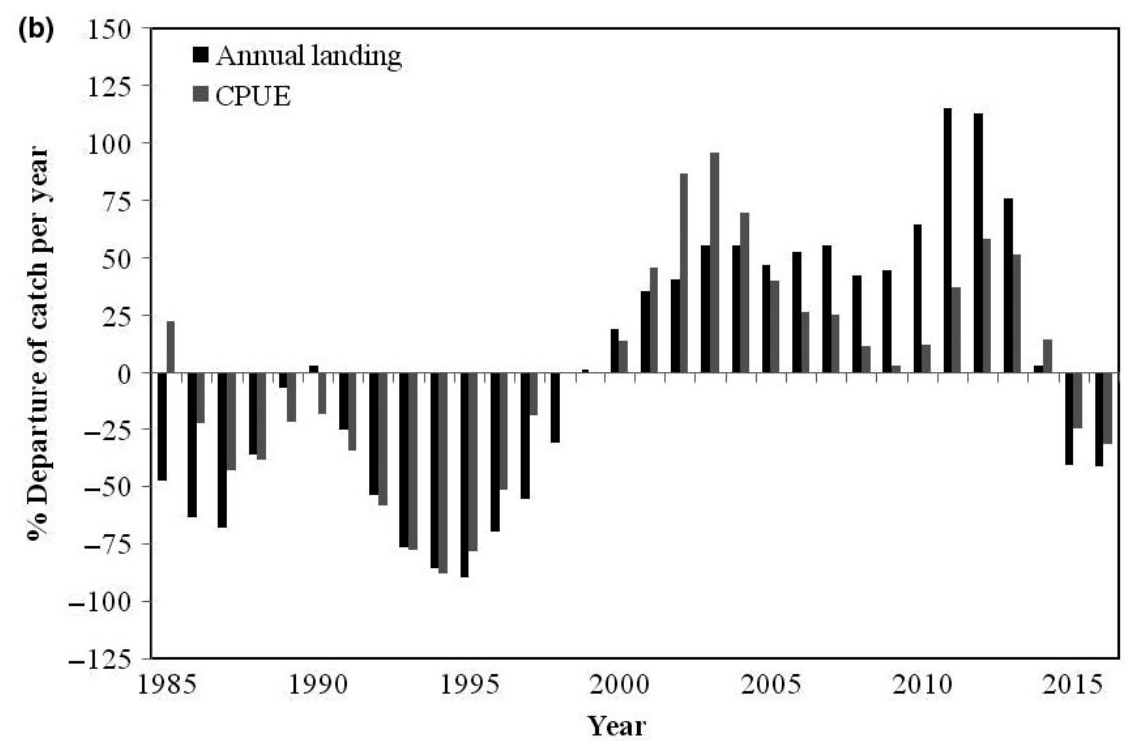

TAB LE 1 Covariance and correlation analysis to identify inter-relationship among environmental parameters and annual landings data of Indian oil sardine (Sardinella longiceps, Clupeidae)

\begin{tabular}{|c|c|c|c|c|c|c|c|c|c|c|c|c|}
\hline & \multicolumn{2}{|c|}{ Landings } & \multicolumn{2}{|l|}{ Chl-a } & \multicolumn{2}{|l|}{ Temp } & \multicolumn{2}{|l|}{ Salinity } & \multicolumn{2}{|l|}{ Curl } & \multicolumn{2}{|l|}{ MLD } \\
\hline $\mathrm{Chl}-a$ & 0.003 & 0.05 & 0.071 & 1 & & & & & & & & \\
\hline Temp & -0.01 & $-0.21^{*}$ & -0.011 & $-0.32^{*}$ & 0.04 & 1 & & & & & & \\
\hline MLD & -0.022 & $-0.38^{* * *}$ & -0.004 & -0.07 & 0.014 & $0.28^{* *}$ & -0.001 & -0.01 & -0.001 & -0.02 & 0.061 & 1 \\
\hline
\end{tabular}

Note: The significant values of correlation coefficient are given as bold and ${ }^{*}$ indicates $10 \%,{ }^{* *}$ indicates $5 \%$ and ${ }^{* * *}$ indicates $1 \%$ significance levels.

concentrated $(>0.4 \mathrm{mg} / \mathrm{ml}$ ) during the surplus years, especially in the fishing zone (which is marked in the Figure). Monthly availability of chl- $a$ during the surplus and deficit years were also analysed (Figure $3 \mathrm{~d}$ ) and found that the average chl- $a$ availability was high during surplus years, especially during the months from May to September. These months are crucial periods concerning sexual maturity, spawning of adults and active feeding of larval forms. 
FIGURE 3 Chlorophyll-a concentration $\left(\mathrm{mg} / \mathrm{m}^{3}\right)$ in the fishing zone during (a) surplus years: the years in which the catch is above $25 \%$ from the mean landings (b) deficit years: the years in which the catch is below $-25 \%$ from the mean landings (c) difference in the concentration of chl- $a$ during the surplus and deficit years (d) annual cycle of monthly availability of chl- $a$ during surplus and deficit years of landings (figure appears in colour in the online version only) [Colour figure can be viewed at wileyonlinelibrary.com]
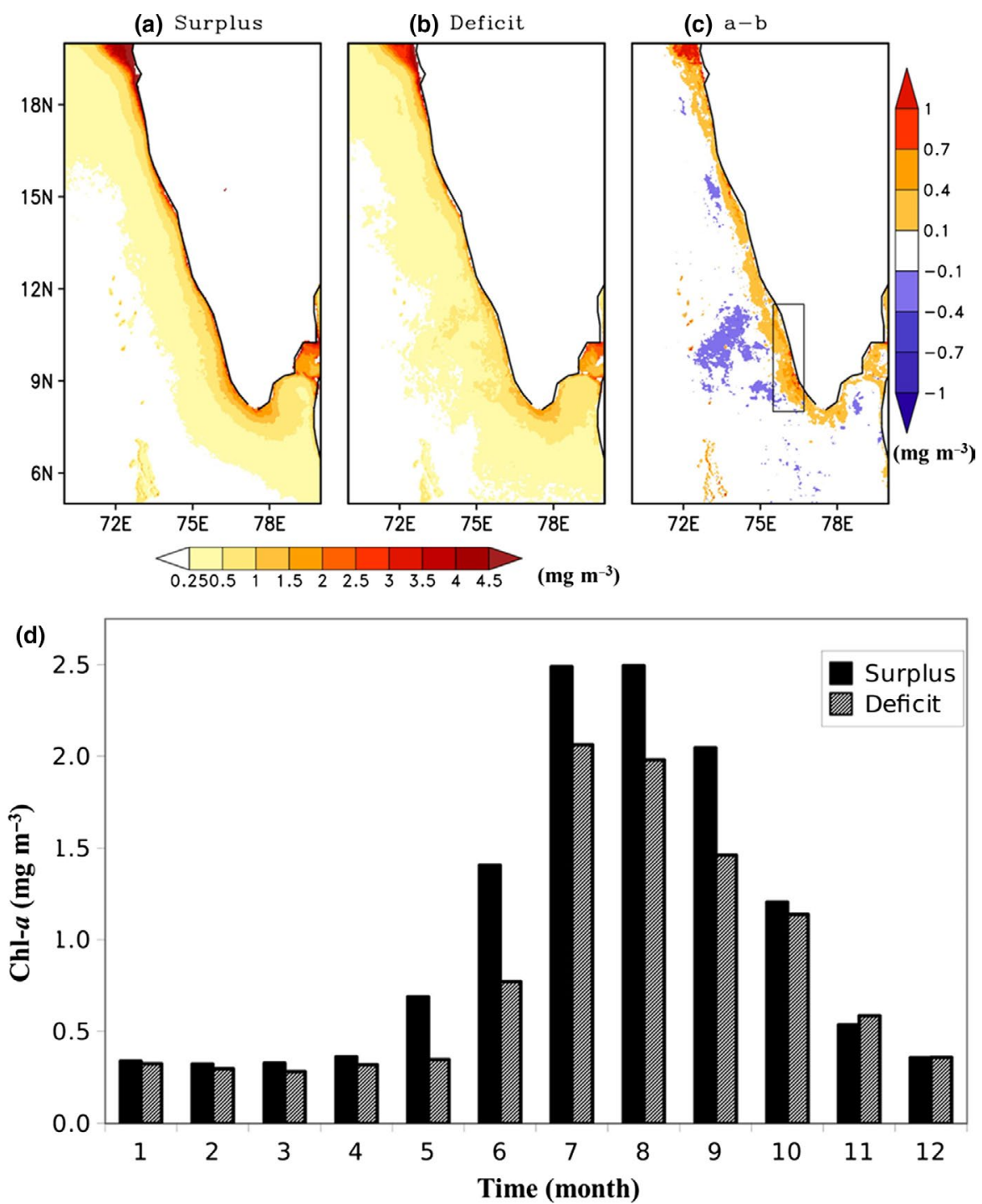

\subsection{Impact of environmental parameters on Indian oil sardine landings}

\subsubsection{Effects of salinity}

Salinity profiles from the surface to $30 \mathrm{~m}$ depth for the surplus and deficit years of landings during different seasons were analysed (contours in Figure 4). The spatial patterns of seasonal fluctuations in salinity were found to be different during surplus and deficit years. During the surplus years, a general increase in salinity values was observed during all four seasons. The seasonal pattern in the SEAS was such that winter and pre-monsoon seasons had below-average salinity, whereas monsoon and post-monsoon season had above-average salinity. On the other hand, the salinity anomaly exhibited an opposite pattern during the deficit years. This indicates that salinity has a significant influence on the landings of Indian oil sardine. In general, the spatial gradient of salinity is higher during surplus years in all four seasons as compared to the deficit years, especially in the pre-monsoon period, which is a physiologically active season for the fish as they attain sexual maturity and undergo spawning during this time.

\subsection{2 | Effects of temperature}

The temperature is observed to be below (above) average during the surplus (deficit) years for all four seasons (shades in Figure 4). In the surplus years, the temperature anomalies over the west coast start to decrease from the winter monsoon and fall to their minima during the monsoon. After that, they show an increase during the post-monsoon season. A basin wide cooling of the entire Arabian Sea occurred during the surplus years and almost an opposite pattern (warming of ocean surface throughout the basin) was observed during the deficit years. In the winter and pre-monsoon periods, the temperature gradually increases and then an abrupt increase was observed in the monsoon season; thereafter, it decreases in the post-monsoon season. The cooling of upper ocean waters during the surplus years is an indication of upwelling that brings nutrient 
(a) Winter (Surplus)

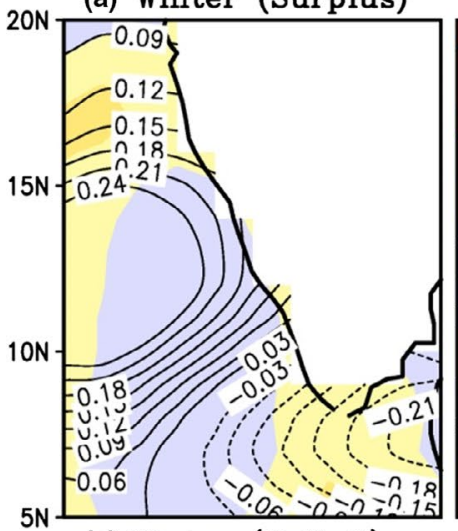

(e) Winter (Deficit)

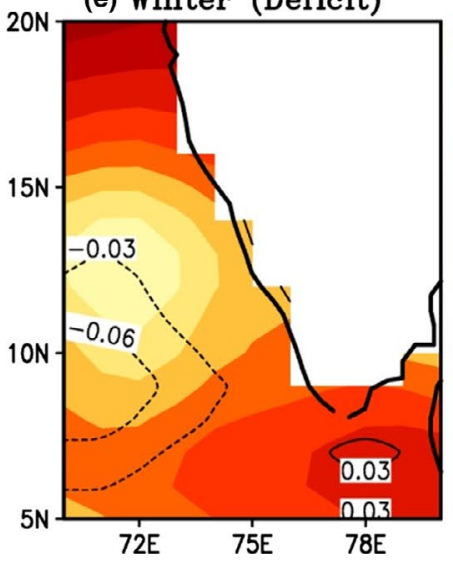

(b) Pre (Surplus)

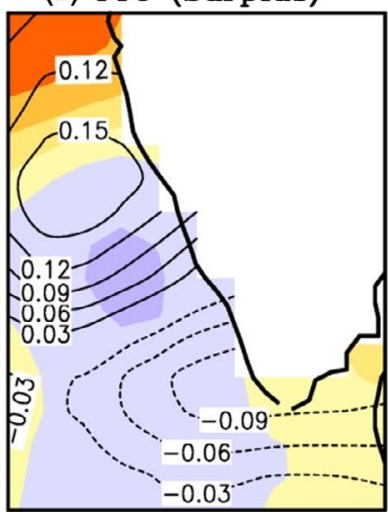

(f) Pre (Deficit)

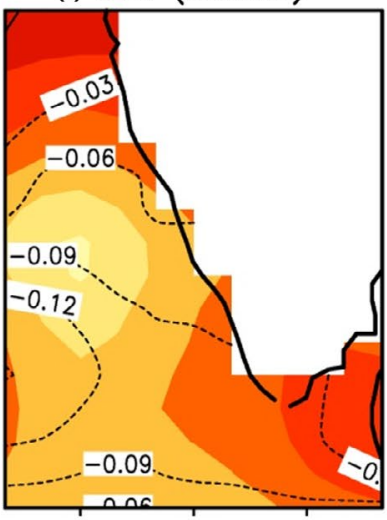

(c) Mon (Surplus)

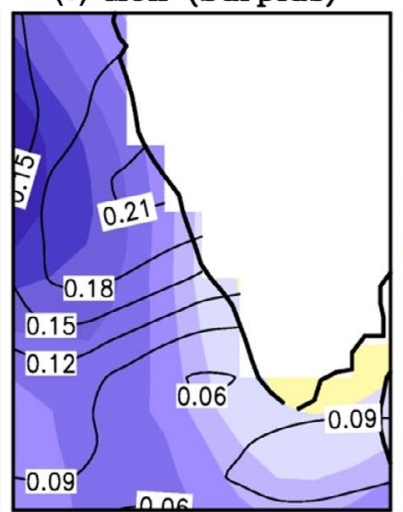

(g) Mon (Deficit)

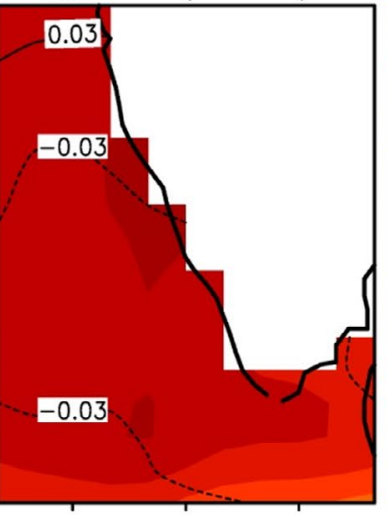

72E $75 \mathrm{E} \quad 78 \mathrm{E}$ (d) Post (Surplus)

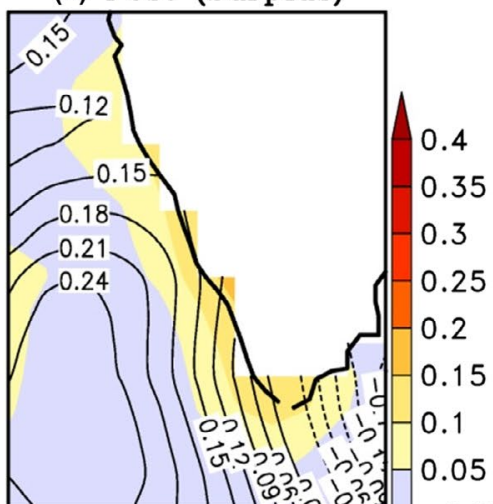

(h) Post (Deficit)

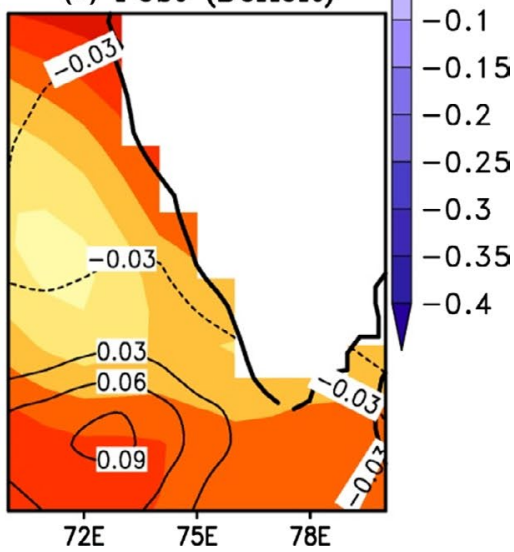

FIGURE 4 The spatial pattern of salinity (\%) in contours and temperature $\left({ }^{\circ} \mathrm{C}\right)$ in shades over a depth of $30 \mathrm{~m}$ water column during the winter, pre-monsoon, monsoon and post-monsoon seasons for the surplus and deficit years of landings. The top panels (a to d) represent the salinity and temperature variations during surplus years and lower panels (e to h) represents deficit years of landings (figure appears in colour in the online version only) [Colour figure can be viewed at wileyonlinelibrary.com]

enriched waters from the below, leading to higher primary production and abundant food for the larvae. The cooling also positively contributes towards physiological processes, including growth and sexual maturation because these temperatures are found within the optimum range $\left(27-28^{\circ} \mathrm{C}\right)$ for the growth and maturation of the oil sardine (Bensam, 1970).

\subsection{3 | Coastal upwelling}

Wind stress curl $\left(\mathrm{N} / \mathrm{m}^{3}\right)$ is used as a measure of upwelling driven by winds. The anomalies of wind stress curl during the surplus and deficit landings years are given in Figure 5 (shades, positive values of anomalies indicate upwelling and negatives indicate downwelling). We observed a downwelling over the entire west coast of India prior to the monsoon season (April-May) during the years of surplus landings. Intense upwelling was noticed in the south-west coastal region during the early monsoon season (June-July) which shifted towards the southern tip of peninsular India by August-September. With the end of the monsoon season, the upwelling zone in the southwest coast was almost dissipated, and a slight downwelling signature started to develop in the northern coastal regions during the October-November period.
In the deficit landings years, we observed an opposite pattern of upwelling as compared to the surplus years. The upwelling zone in the SEAS was dissipated or weakened in the early monsoon period itself, and it continued to be weak towards the latter period of monsoon during the deficit years. The upwelling signature was noticed by October-November of the deficit years.

\subsection{4 | Ocean mixed layer depth}

The mixed layer depth (MLD) was shallower during all the seasons of surplus landings years (Figure 6) compared to the mean. The shoaling of MLD started prior to the monsoon season (AprilMay), which was further shoaled during the early monsoon season (June-July). Afterwards, MLD started to deepen during the late monsoon season (August-September) but shoaled again during the October-November period. In the case of deficit years, MLD started to deepen before the monsoon period (April-May) and reached the maximum depth in the early monsoon season (JuneJuly), followed by mild shoaling during the August-September period, and further deepening during the post-monsoon season (October-November). 
(a) AM (Surplus)

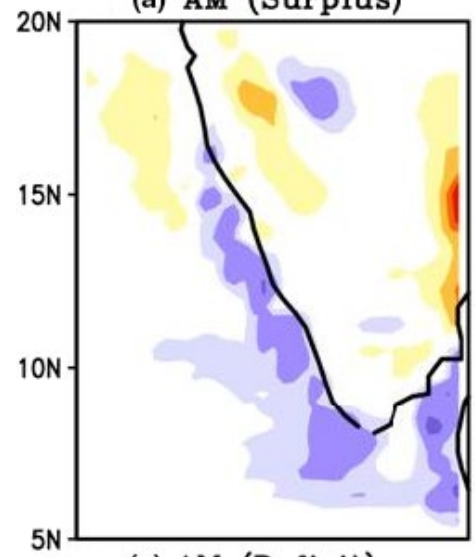

(e) AM (Deficit)

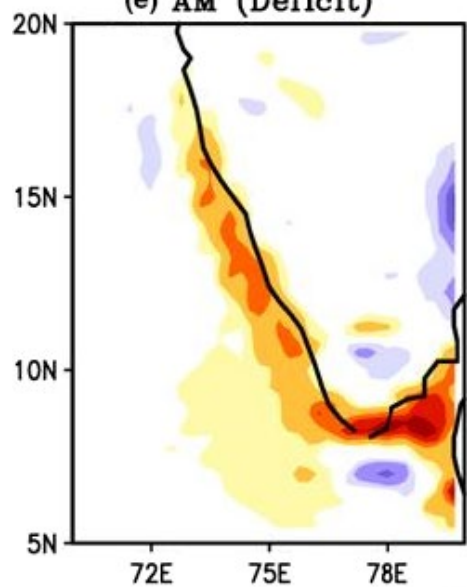

(b) JJ (Surplus)

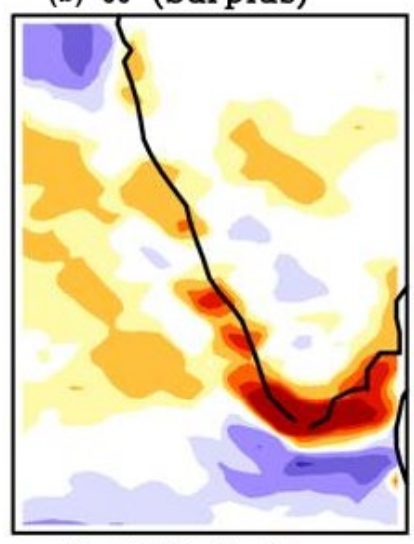

(f) JJ (Deficit)

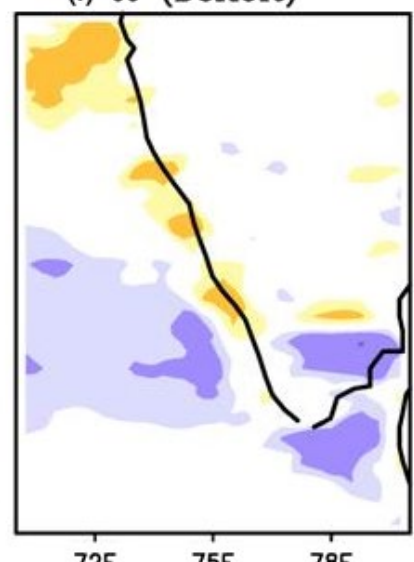

(c) AS (Surplus)

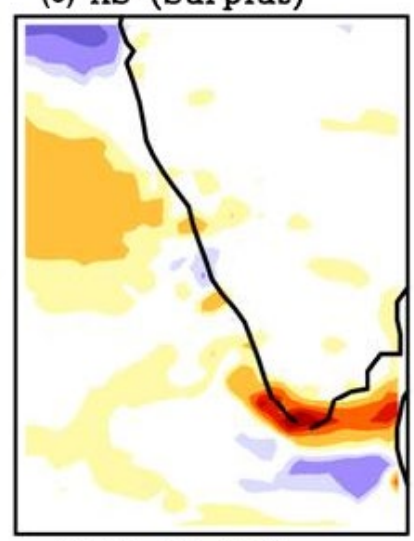

(g) AS (Deficit)

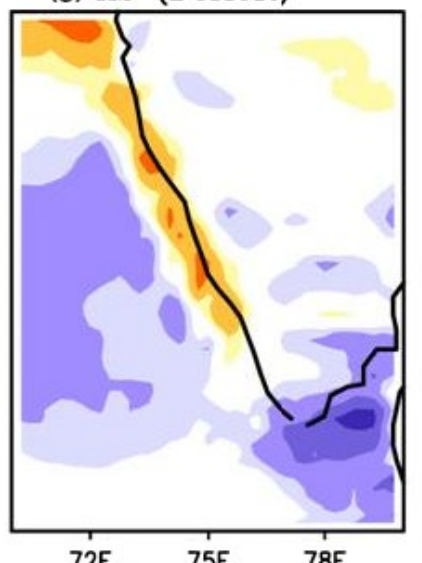

(d) ON (Surplus)

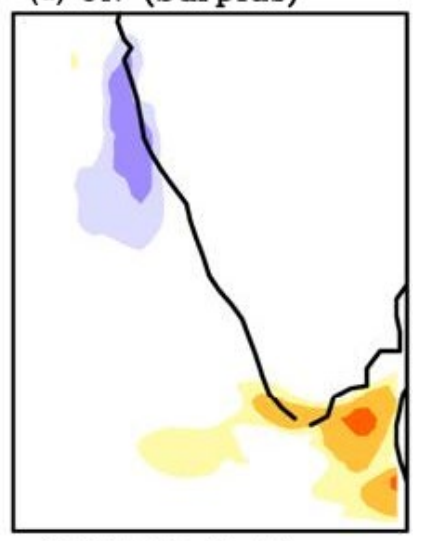

(h) ON (Deficit)

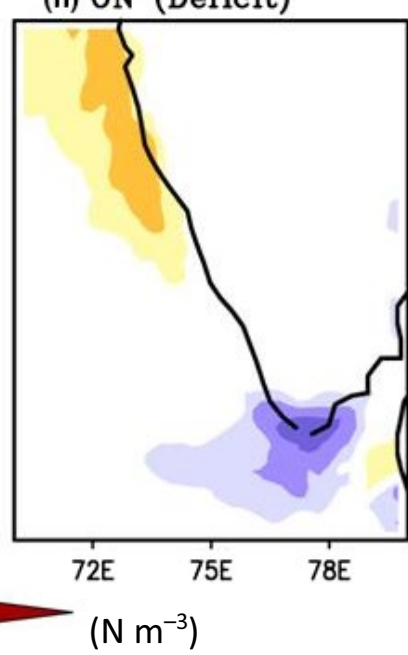

FIGURE 5 Bimonthly spatial distribution of wind stress curl anomalies $\left(\mathrm{N} / \mathrm{m}^{3}\right)$ as a measure of upwelling driven by surface winds during surplus (upper panels) and deficit (lower panels) landings years from April to November (figure appears in colour in the online version only) [Colour figure can be viewed at wileyonlinelibrary.com]

\subsection{Long- and short-term variability of environmental parameters and impact on Indian oil sardine landings}

Surplus and deficit landings years (Figure 7a,b for CASE-1 and CASE2 , respectively) were differentiated in the long-term and short-term cases (CASE-1 and CASE-2; see Section 2 for details). The interplay of environmental parameters in the surplus and deficit years of both cases was analysed. Ideally, CASE-1 and 2 explain the features identified from Figures 4-6, either individually or as a combination of both.

\subsection{1 | Salinity}

The seasonal fluctuations in salinity for the surplus and deficit years of annual landings data (Figure 4; contour) were found to be matching with the CASE-1 (Figure 8; contour) except for the post-monsoon season of deficit years which has more resemblance to that of CASE-2 (Figure 9h; contour). These results indicate that the salinity fluctuation observed in annual landing data was mostly contributed from a long cycle as depicted in CASE-1.

\subsection{2 | Temperature}

The temperature patterns for the surplus years of annual landings data (Figure $4 \mathrm{~b}-\mathrm{d}$; shades) were found to be mainly contributed from the long cycle (i.e. CASE-1; Figure $8 b-d$; shades) except for the winter season (Figure 4 a), which appears as a contribution from both CASE-1 (shades in the Figure 8a) and CASE-2 (shades in the Figure 9a). The temperature pattern of the annual landings data during the deficit years (Figure 4; shades in the lower panel) also has more resemblance towards that of CASE-1 (Figure 8; shades in the lower panel), except for the winter (Figure 4e) and post-monsoon seasons (Figure $4 \mathrm{~h}$ ) which appeared as a combination of both the cases (Figures $8 \mathrm{e}, 9 \mathrm{e}$ and Figures $8 \mathrm{~h}, 9 \mathrm{~h}$ for winter and post-monsoon, respectively). However, for the post-monsoon season, the significant contribution was from CASE-2 (shades in the Figure 9h). This analysis indicates that the temperature fluctuations were contributed by both the long- (CASE-1) and short (CASE-2)-term variability.

Similar analyses were performed for coastal Upwelling and MLD also. For these parameters, CASE-1 and CASE-2 also explain the features identified from Figure 5 (upwelling) and 6 (MLD). Details are provided in the supplementary materials (Figures S1-S4). 
(a) AM (Surplus)

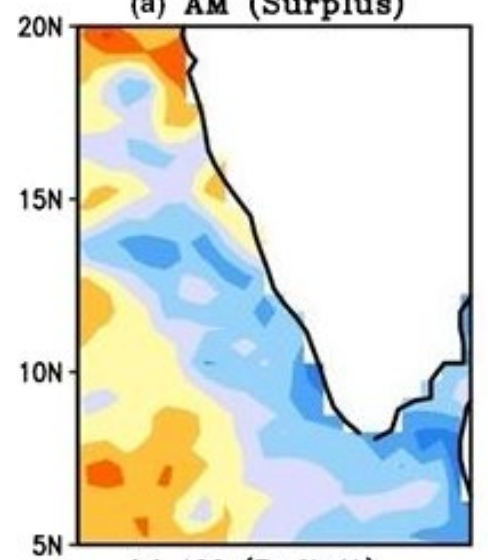

(e) AM (Deficit)

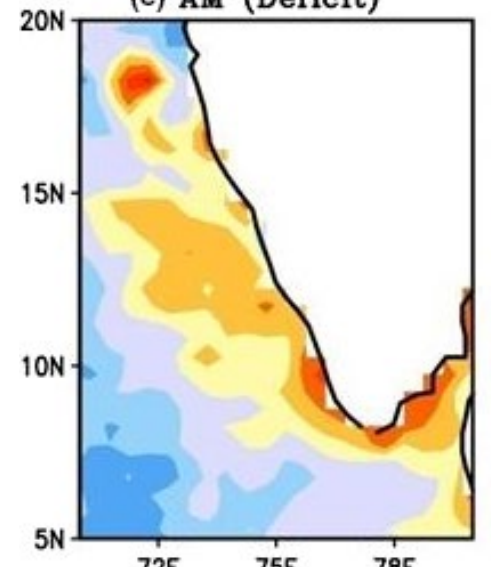

$72 E$ (b) JJ (Surplus)

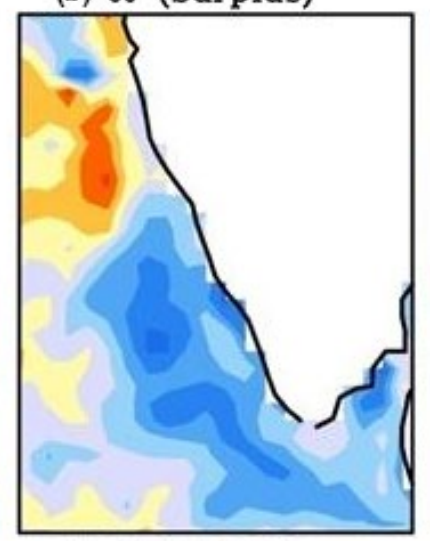

(f) JJ (Deficit)

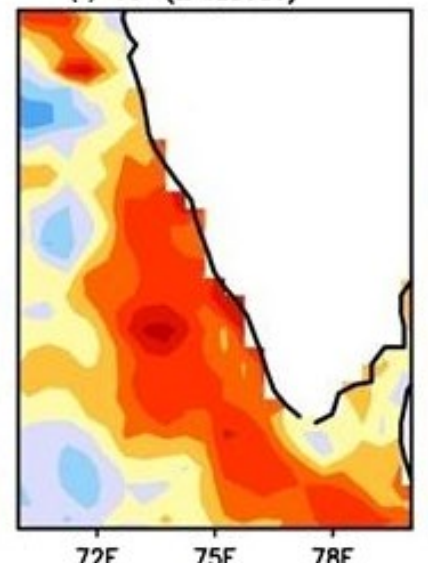

(c) AS (Surplus)

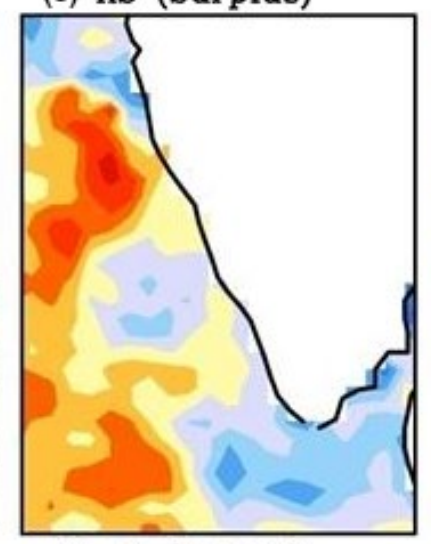

(g) AS (Deficit)

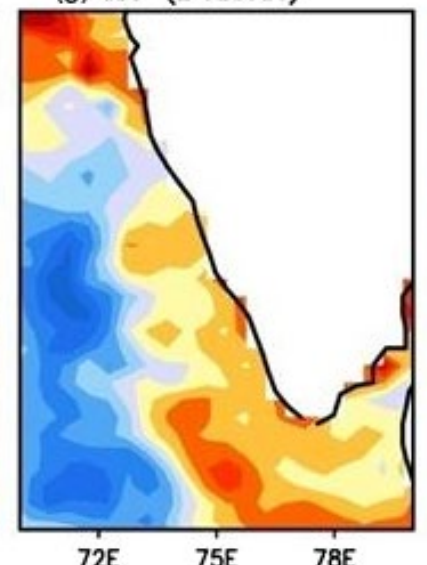

(d) ON (Surplus)

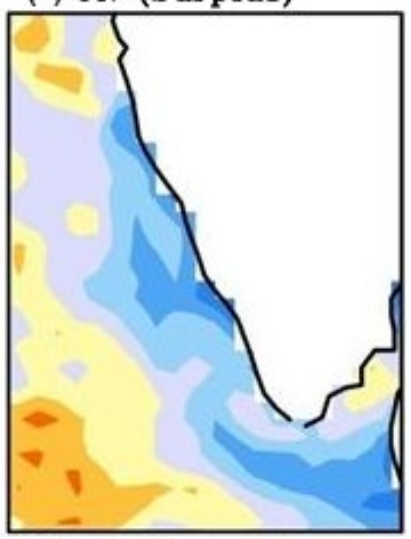

(h) ON (Deficit)

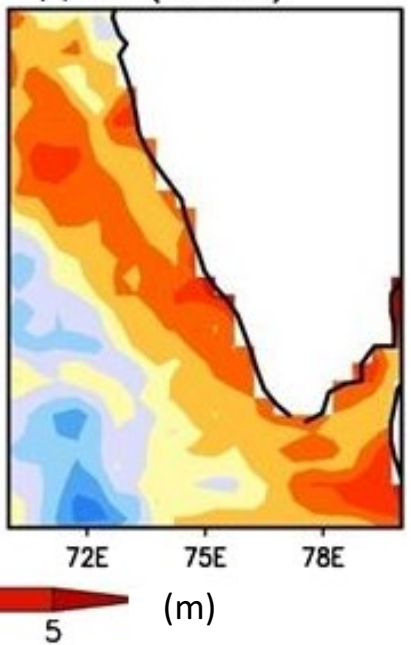

FIGURE 6 Bimonthly spatial distribution of mixed layer depth anomalies (m) during surplus (upper panels) and deficit (lower panels) landings years from April to November (figure appears in colour in the online version only) [Colour figure can be viewed at wileyonlinelibrary. com]

\subsection{Connection of climatological indices to annual landings of Indian oil sardine}

The time series of sardine catch anomaly and climate indices from 1962 to 2017 are given in Figure 10. From the time series, it is evident that the variability of catch anomaly showed an out-of-phase relationship with PDO and NAO, whereas it was in-phase with the AMO index. The other indices did not show a strong relation with catch anomaly; however, the ENSO (i.e. El Niño/La Niña index) showed an inverse relationship. In order to analyse the relationship in detail, the correlation coefficient between annual landings and climate indices and their significance based on the Student $t$ test were determined. The correlation coefficients between different climatological indices and annual landings data of Indian oil sardine along with their long and short cycles for a period spanning from 1962 to 2017 are given in Table 2. Among the indices, the PDO has an out-ofphase relationship with the annual landing data with a correlation value of -0.47 , which is significant at the $1 \%$ level. Besides, PDO also displayed a significant negative correlation with the long-term variability (99\% confidence level) and short variability
(95\% confidence level) of Indian oil sardine landings. However, the relationship of AMO is in-phase with the annual landings data with a correlation coefficient of 0.32 , and this is statistically significant at the $5 \%$ level. The AMO was also found to be more significantly correlated (at $99 \%$ confidence) with the long cycle of annual landings data. Another prominent out-ofphase relationship was with the short cycle of annual landings data and the ENSO index with a correlation value of -0.3 (95\% confidence level). The results of this analysis indicate that the effect of ENSO on this pelagic resource could be on a short-term basis, and more prominent long-term effects could be due to the climate forcings such as from PDO and AMO. Further, we calculated the wind stress curl (indicative of upwelling) for the significantly negative PDO (less than one standard deviation). An anomalous upwelling of water is observed at the SEAS during this period, as indicated in Figure 11.

We also analysed the variabilities of other commercially important pelagic fish species along with Indian oil sardine in the Indian coastal waters to identify their coherence in exhibiting variability. The selected pelagic fishes were Indian mackerel (Rastrelliger kanagurta, Scombridae), two species of anchovies 
FIGURE 7 Temporal variability of reconstructed landings data by spectral decomposition (a) percentage of deviation from mean landings for the long cycle (CASE-1: variability of 11 years and above) (b) percentage of deviation from mean landings for the short cycle (CASE-2: variability of 10 years and below)
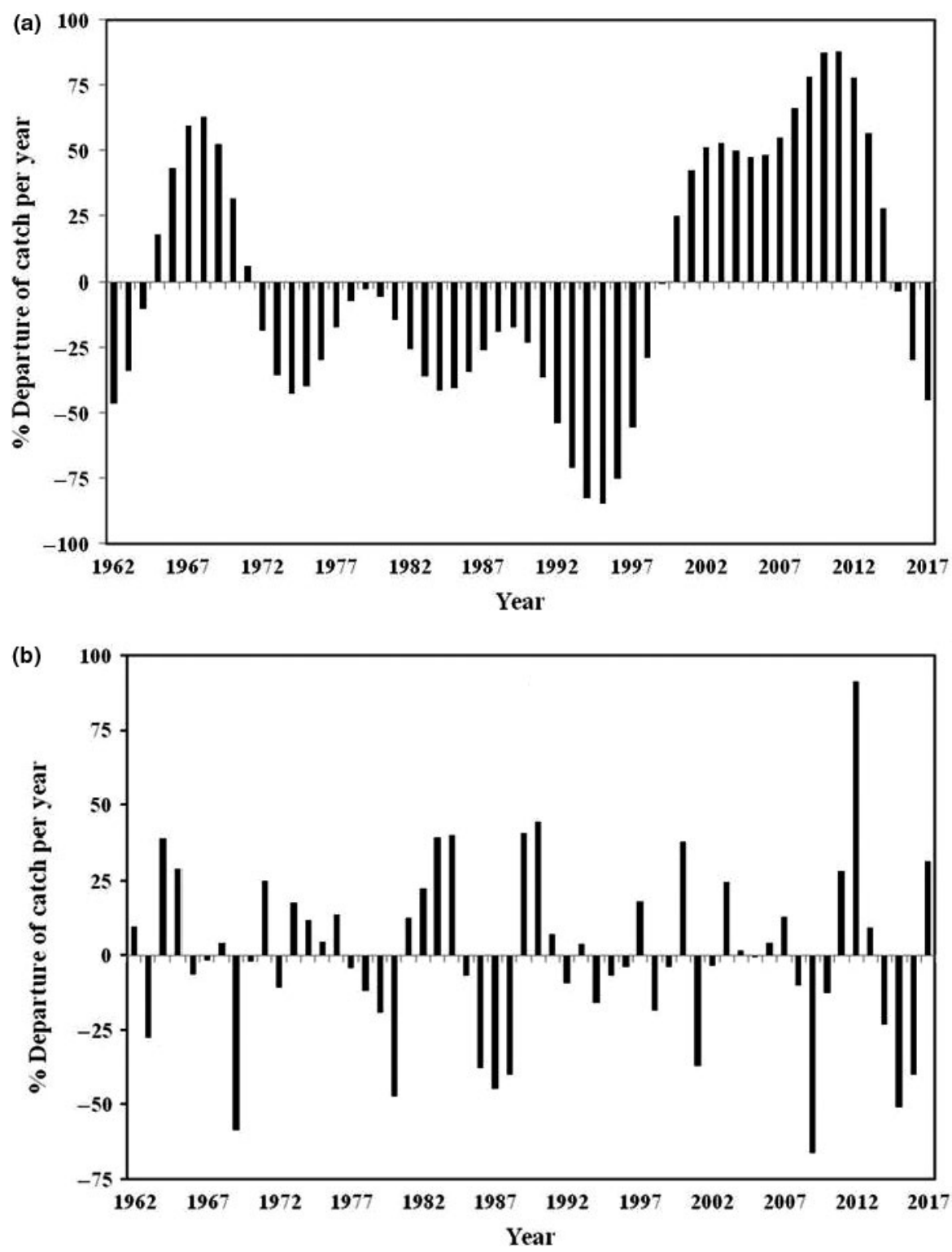

(Stolephorus sp., Engraulidae and Thryssa sp., Engraulidae), ribbon fish (Trichiurus sp., Trichiuridae) and silver bellies (Gerres sp., Gerreidae). Indian mackerel and one of the anchovy (Stolephorus sp.) displayed year to year and interdecadal variability in their landings; however, Indian oil sardine displayed dominant decadal variability (Figure 12a-c). The remaining three species (Thryssa sp., Trichiurus sp., and Gerres sp.) did not display any mode of dominant variability in landings other than a continuous increase due to the increased effort in fishing over the time (Figure 12d-f). These three species show embedded minor interdecadal variability along with a consistent increase in their landings. Moreover, for all these species the years of abundance and decline are not coherent with the Indian oil sardine. It indicates that the climate forcing may have a different influence on these species than on Indian oil sardine. It has to be highlighted that the peculiar situation of the Indian oil sardine with periods of decline close to extinction and periods of extreme abundance could not be seen in any of the other pelagics considered for this study.

\section{4 | DISCUSSION}

The present study reaffirms the influence of environmental parameters in determining the variability in landings of Indian oil sardine in the SEAS, as the earlier studies that examined the sardine production fluctuations around the globe (Chavez et al., 2003; IzquierdoPeña et al., 2019). We noticed a higher concentration of chl- $a$ in the SEAS during the years of surplus sardine landings, especially in the months of spawning and active feeding of larvae. These results are in agreement with the earlier reports that the migratory pattern of oil sardine during their active breeding phase mainly depends on the availability of average chl- $a$ in these months (George et al., 2012). We also noted an increase in chl- $a$ availability in the month of May itself and this could be favourable for early spawners of the season. Antony Raja (1970) observed that the success of oil sardine fishery along this coast is mainly dependent on the successful spawning and survival rate in that year. An elevated chl-a concentration during the monsoon season results in increased recruitment and catch of 
(a) Winter (Surplus)
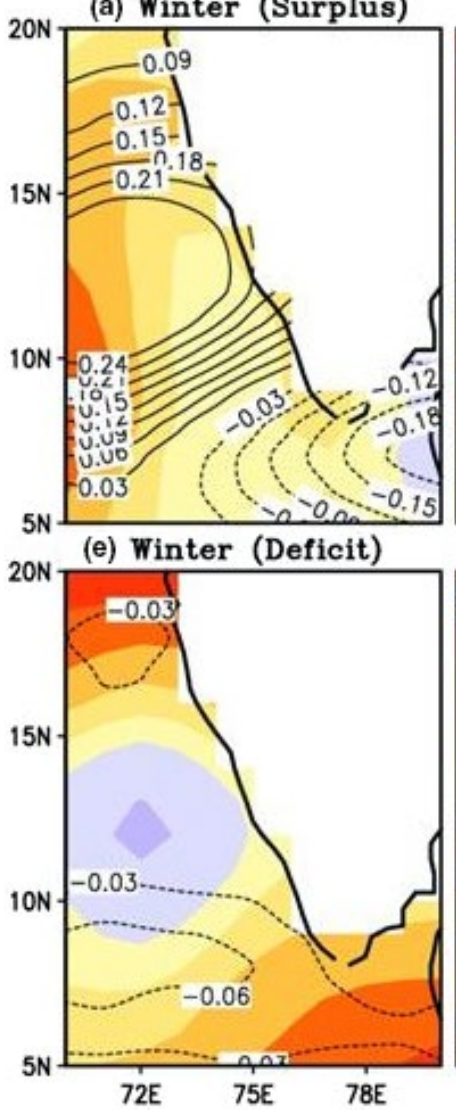

(b) Pre (Surplus)

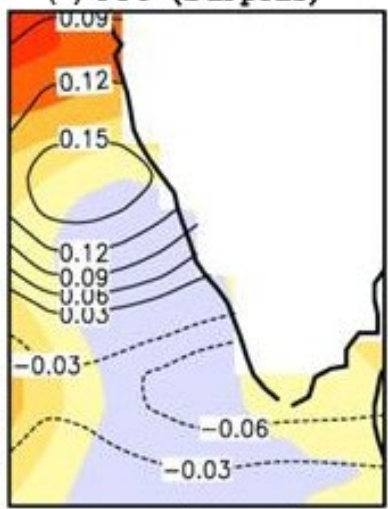

(f) Pre (Deficit)

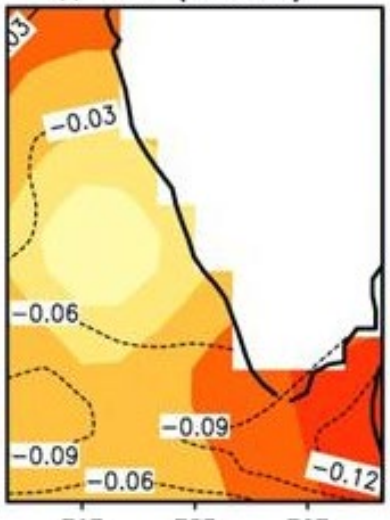

(c) Mon (Surplus)

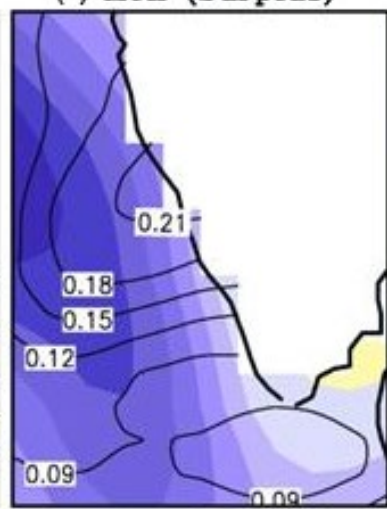

(g) Mon (Deficit)

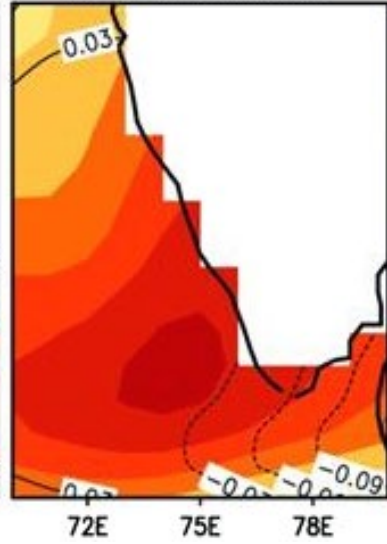

(d) Post (Surplus)

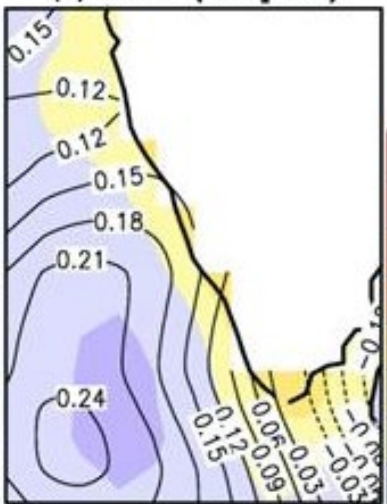

0.4

0.35

0.3

0.25

0.2

0.15

0.1

0.05

(h) Post (Deficit)

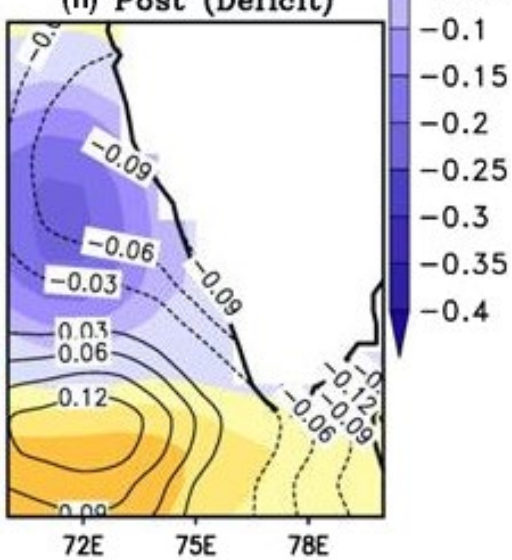

FIGURE 8 Spatial patterns of salinity $(\%)$ in contours and temperature $\left({ }^{\circ} \mathrm{C}\right)$ in shades over a depth of $30 \mathrm{~m}$ water column during the winter, pre-monsoon, monsoon and post-monsoon seasons for surplus (upper panels) and deficit (lower panels) years of landings for the long cycle (CASE-1) (figure appears in colour in the online version only) [Colour figure can be viewed at wileyonlinelibrary.com]

small pelagic, including oil sardine along the Kerala coast (Manjusha et al., 2013). Besides, lack of food during the period of sexual maturity in the deficit years could lead to a condition of gonad atrophy or poor sexual maturity in Indian oil sardine (Kripa et al., 2018; Silva et al., 2006).

In the surplus years of landings, it is observed that high salinity during the monsoon season positively contributes towards the high survival of larvae and juveniles (Bensam, 1970; Kripa et al., 2018; Moyle \& Cech, 2004). Our results for the years of surplus landings show a decrease in salinity during the pre-monsoon period (notably the spawning season for Indian oil sardine) and an increase during the monsoon period. In general, sardines prefer lower salinity during the spawning period (Twatwa et al., 2005) and higher salinity for larval recruitment success (Bal \& Rao, 1990). This implies that the natural freshening of the SEAS during the monsoon season may have deleterious effects on fish due to stratification, especially on the larvae and juveniles. Years with higher salinity during the monsoon season are thus found to be favourable for Indian oil sardine production in the SEAS.

The present study reveals that colder temperature in the SEAS favours the landings of Indian oil sardine during the surplus years. It is established that lower temperature in the optimum range for sardines favours better growth, metabolic activities, reproductive maturity, spawning and larval survival of fish (Joseph \& Jayaprakash, 2003;
Morales-Bojórquez et al., 2003). Change in temperature can cause extensive changes in the distribution of small pelagic fish (Cheung et al., 2016; Fiedler 2002). The anomalous warming of ocean water was observed during the monsoon season (i.e. peak spawning season) in deficit landings years, disrupting the spawning season and affecting the fishery as the spawning of this species could not be shifted to other periods of the year.

The optimum temperature and salinity for survival, growth and spawning of sardines may vary according to species and region. For example, European pilchard (Sardina pilchardus, Clupeidae) along western Portugal preferred a low salinity $(<35.8 \%$ ) and temperature $\left(<16^{\circ} \mathrm{C}\right)$. In contrast, the sardine from the northern Aegean Sea prefers warmer temperature range $\left(20-24^{\circ} \mathrm{C}\right.$ ) (Giannoulaki et al., 2005). Across the north-eastern Atlantic margin and the Mediterranean Sea, the preferred salinity range was 30-38\% (Giannoulaki et al., 2005; Petitgas et al., 2006) with temperatures ranges between $8{ }^{\circ} \mathrm{C}$ and $24^{\circ} \mathrm{C}$ (Giannoulaki et al., 2005; Haynes \& Nichols, 1994; Stratoudakis et al., 2007). Off the Moroccan coast, spawning is observed within the temperature range $16-18.5^{\circ} \mathrm{C}$ (Ettahiri et al., 2003). For the Pacific sardine (Sardinops sagax, Clupeidae) along the north Pacific, the optimum thermal range is reported as $13.5-17^{\circ} \mathrm{C}$ (Lluch-Belda et al., 1991; Parrish et al., 1989). However, along the southern and central California, the colder temperature of $12-13^{\circ} \mathrm{C}$ was preferred by sardine. A bimodal spawning temperature range was observed 
(a) Winter (Surplus)

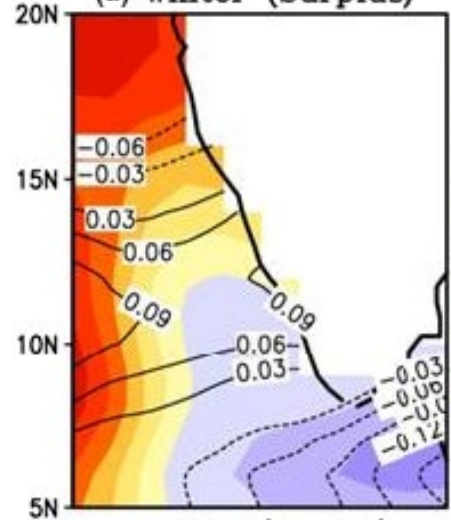

(e) Winter (Deficit)

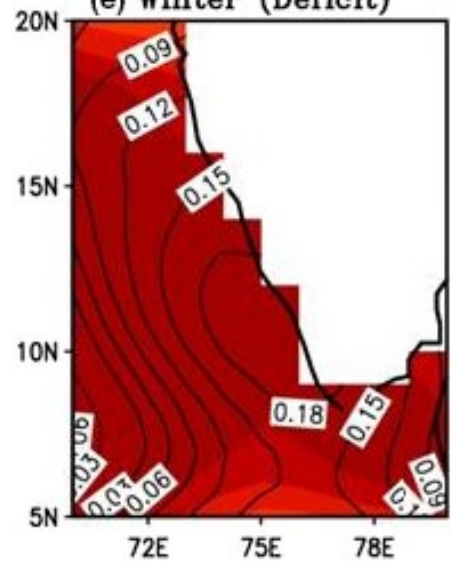

(b) Pre (Surplus)

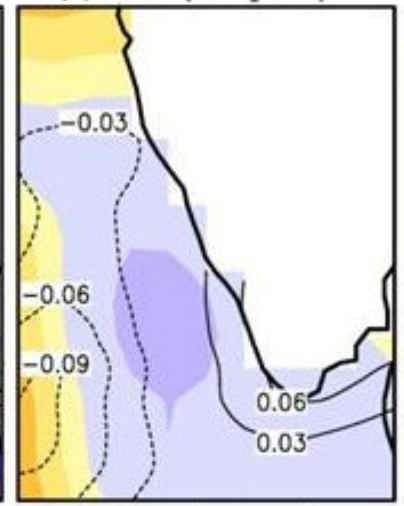

(f) Pre (Deficit)

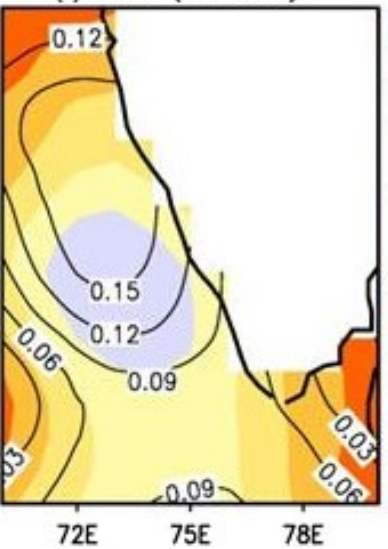

(c) Mon (Surplus)

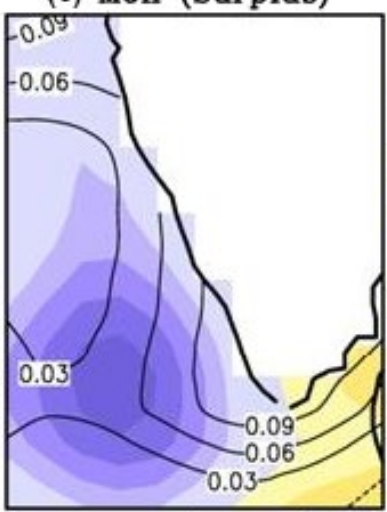

(g) Mon (Deficit)

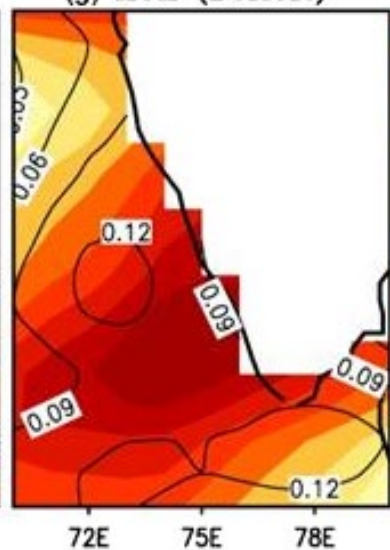

(d) Post (Surplus)

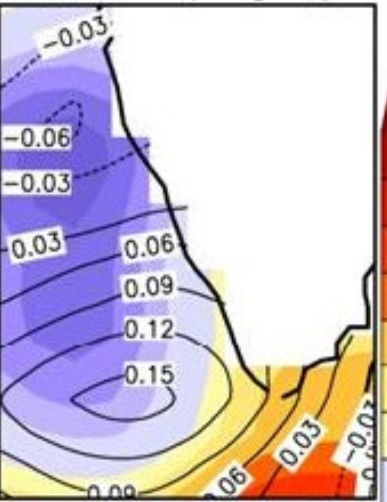

(h) Post (Deficit)

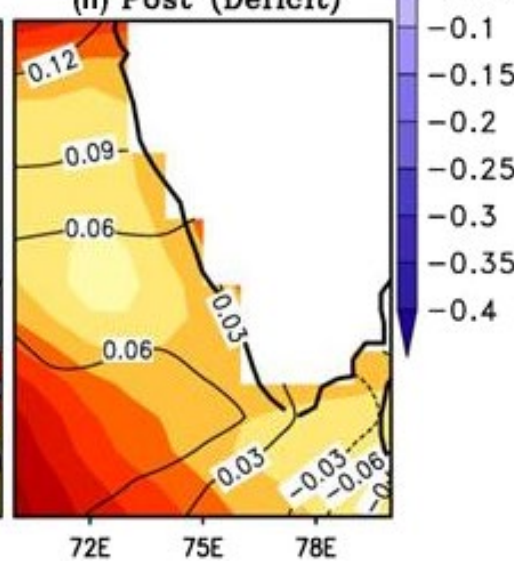

FIGURE 9 Spatial patterns of salinity $(\%)$ in contours and temperature $\left({ }^{\circ} \mathrm{C}\right)$ in shades over a depth of $30 \mathrm{~m}$ water column during the winter, pre-monsoon, monsoon and post-monsoon seasons for surplus (upper panels) and deficit (lower panels) years of landings for short cycle (CASE-2) (figure appears in colour in the online version only) [Colour figure can be viewed at wileyonlinelibrary.com]

with a primary peak at $15.5-17.5^{\circ} \mathrm{C}$ and a secondary peak between 18.7 and $20.5^{\circ} \mathrm{C}$ over the Benguela upwelling system (Van der Lingen et al., 2001). However, all these temperature ranges are much below the mean temperature of the equatorial region or the study region, where the mean temperature is above $28^{\circ} \mathrm{C}$. Therefore, sardine of this study basin always prefers the optimum temperature values below the mean, which is also in consensus with the earlier findings.

Indian oil sardines display an offshore to coastal water migration for spawning and feeding (Jayaprakash, 2007; Krishnakumar \& Bhat, 2008; Rohit et al., 2018). During the surplus landings years, downwelling during April-May period favoured the coastal migration of spawners (as the Ekman transport is towards the coast), which was not observed during the deficit landings years. During the early monsoon months of the surplus landings years, we observed a unique upwelling pattern, which makes this area an ideal habitat for the newly hatched sardine larvae and juveniles as described by Kripa et al. (2015).

We observed shoaling (deepening) of MLD during the surplus (deficit) years. The observed shoaling of MLD may lead to good catch of Indian oil sardine as the fishing operations in this region are mostly around 30-40 m depth. Similarly, in the south-eastern Brazilian Bight, the Brazilian Sardinella (Sardinella brasiliensis, Clupeidae) was also found in the upper mixed layer. When this species and southwest Atlantic anchovy (Engraulis anchoita, Engraulidae) share the same habitat, they segregate vertically, and S. brasiliensis prefer to stay in the upper mixed layer, whereas the E. anchoita occupies in the bottom layer (Schwartzlose \& Alheit, 1999).

Even though the relations between Indian oil sardine landings in the SEAS and leading climate indices are identified in this study, reasons for such relationships are not explored further here. The influence of PDO and AMO were found to be more significant than that of NAO and ENSO on the annual landings of Indian oil sardine in the SEAS. The PDO (AMO) was found to have an out-of-phase (in-phase) relationship with the annual landings. A mechanism of this relationship is explored further by calculating the wind stress curl (indicative of upwelling) for those years when the PDO index is significantly negative. In the SEAS, an anomalous upwelling of water is noted during negative PDO years (Figure 11). Zhang, and Delworth, (2006) have observed an in-phase relationship between Indian summer monsoon and AMO. Further, Hu et al. (2018) have found large-scale southward wind along the coast of SEAS favouring upwelling during the positive phase of AMO (Figure $6 c$ in the referred article). The negative PDO and positive AMO are causing upwelling conditions in the SEAS, which could lead to the nutrient enrichment and thereby abundance of food to sardine during the surplus years of landings. A relationship between the food availability and Pacific sardine (Sardinops sagax, Clupeidae) during PDO events has been established in the Pacific Ocean by Zwolinski and Demer (2014); however, 

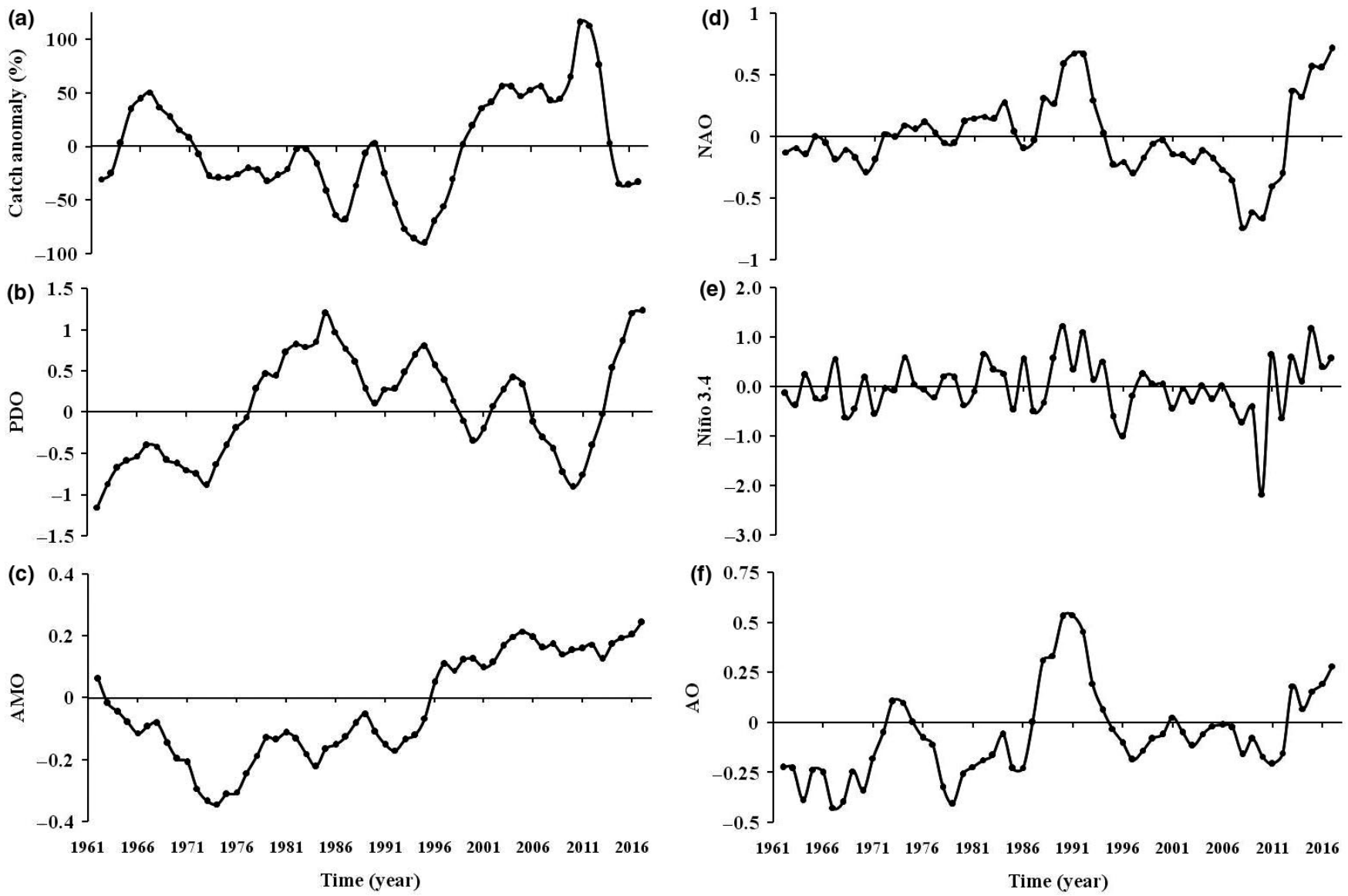

FIGURE 10 Annual times series of (a) catch anomaly of Indian oil sardine, (b) Pacific decadal oscillation (PDO), (c) Atlantic multidecadal oscillation (AMO), (d) North Atlantic oscillations (NAO), (e) Niño 3.4 index (a measure of El Niño/La Niña) and (f) Arctic oscillation (AO) for the period of 1962-2017

TABLE 2 Correlation coefficients between different climatological indices and annual landings data of Indian oil sardine along with its long (variability of 11 years and above) and short (variability of 10 years and below) cycles for a period spanning from 1962 to 2017

\begin{tabular}{|llll|}
\hline Indices & $\begin{array}{l}\text { Annual landings } \\
\text { data }\end{array}$ & $\begin{array}{l}\text { Long cycle/ } \\
\text { CASE-1 }\end{array}$ & $\begin{array}{l}\text { Short } \\
\text { cycle/ } \\
\text { CASE-2 }\end{array}$ \\
\hline PDO & $-0.47^{\mathrm{a}}$ & $-0.39^{\mathrm{a}}$ & $-0.27^{\mathrm{b}}$ \\
\hline AMO & $0.32^{\mathrm{b}}$ & $0.43^{\mathrm{a}}$ & -0.1 \\
\hline NAO & -0.17 & $-0.29^{\mathrm{b}}$ & 0.14 \\
\hline Niño 3.4 & -0.26 & -0.12 & $-0.3^{\mathrm{b}}$ \\
\hline AZM & 0.03 & 0.15 & -0.18 \\
\hline AO & 0.02 & -0.18 & $0.32^{\mathrm{b}}$ \\
\hline DMI & 0.11 & 0.12 & 0.01 \\
\hline
\end{tabular}

${ }^{\mathrm{a}} 99 \%$ confidence level.

${ }^{\mathrm{b}} 95 \%$ confidence level.

such studies are hitherto not reported in the Indian Ocean regions, making our study a pioneer one in the field.

Alheit et al. (2019) are of the opinion that the regime shift recorded in all biota of the pelagial in the northeast Atlantic and
Mediterranean Sea during the mid-1990s is a climate induced one. This climate induced shift was caused by complex ocean-atmosphere interactions, including a substantial strengthening of $\mathrm{AMO}$ and a weakening of NAO. In the present study also, we observed a similar shift in the annual landings of sardine, but with a lag of 6 years from that recorded by Alheit et al. (2019). The NAO was found to be negatively correlated (with a 95\% confidence level) with the long cycle of annual sardine landings data.

Additionally, we observed a negative correlation value of -0.26 (90\% confidence level) between the annual landings and ENSO index. However, the relationship was statistically more significant (95\% confidence level) with CASE-2 ( $r=-0.3)$. This improvement in significance may be due to the 2-7-year dominant periodicity of the ENSO cycle (Cane, 2005), which was almost coherent with the periodicity of the short cycle of landings. Kripa et al. (2018) postulated the warming in the Indian Ocean induced by EI Niño in 2015 was a possible reason for the decline in the production of oil sardines in the SEAS coastal waters. The impacts of El Niño on small pelagics, especially on the species depending on the feeding and spawning ground in coastal water, is short term and the organisms generally recover within a few years. However, decadal variability in climate has caused changes in populations (especially in small pelagics) and communities that cannot recover within a 
FIGURE 11 Composite anomalies of wind stress curl $\left(\mathrm{N} / \mathrm{m}^{3}\right)$ to indicate upwelling during the years of (a) positive and (b) negative PDO index. Positive values of wind stress curl indicate upwelling (figure appears in colour in the online version only) [Colour figure can be viewed at wileyonlinelibrary.com] (a) PDO +ve

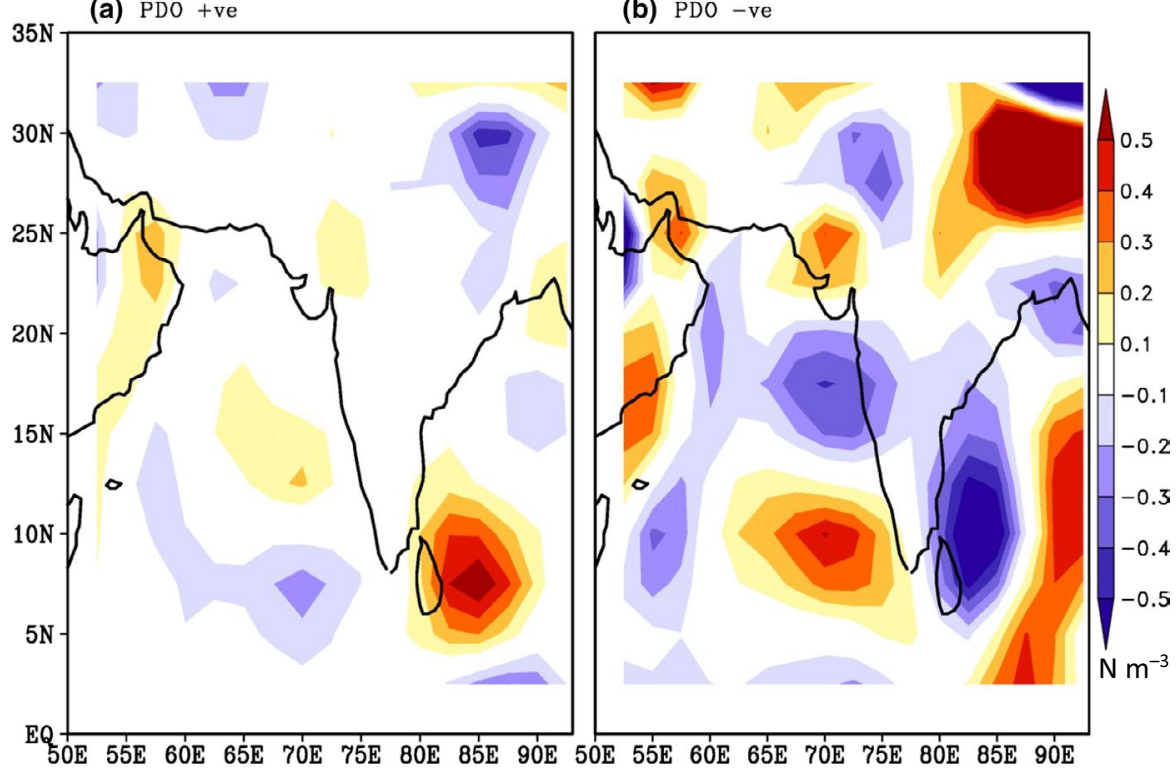

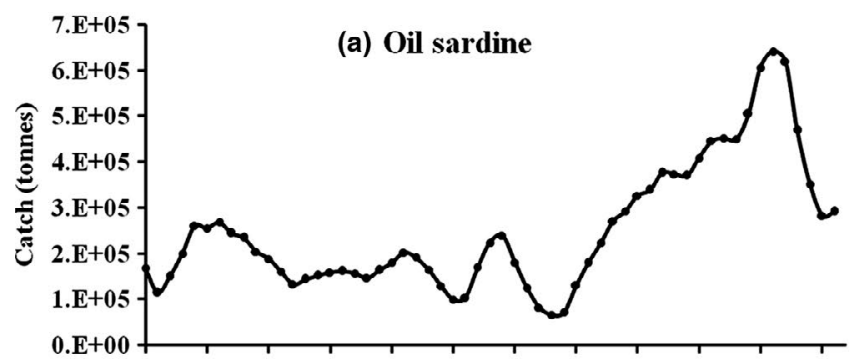
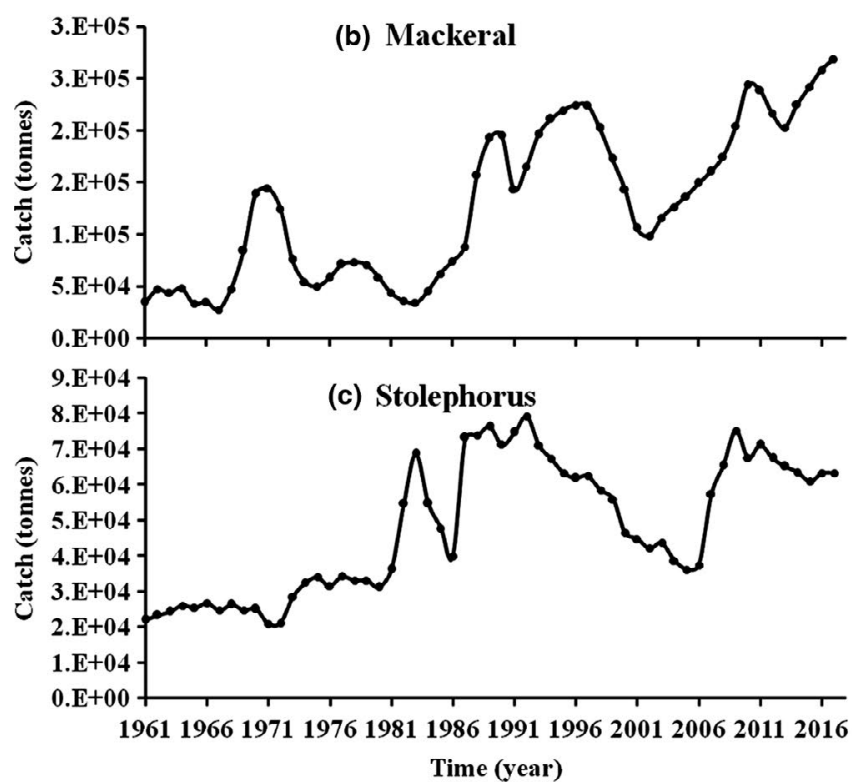

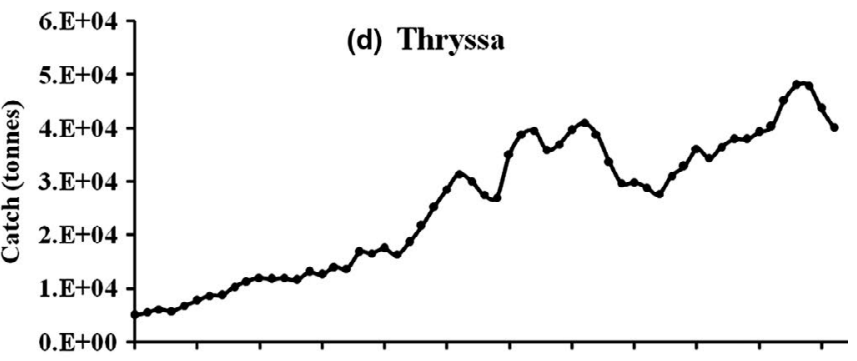

(e) Ribbon fish
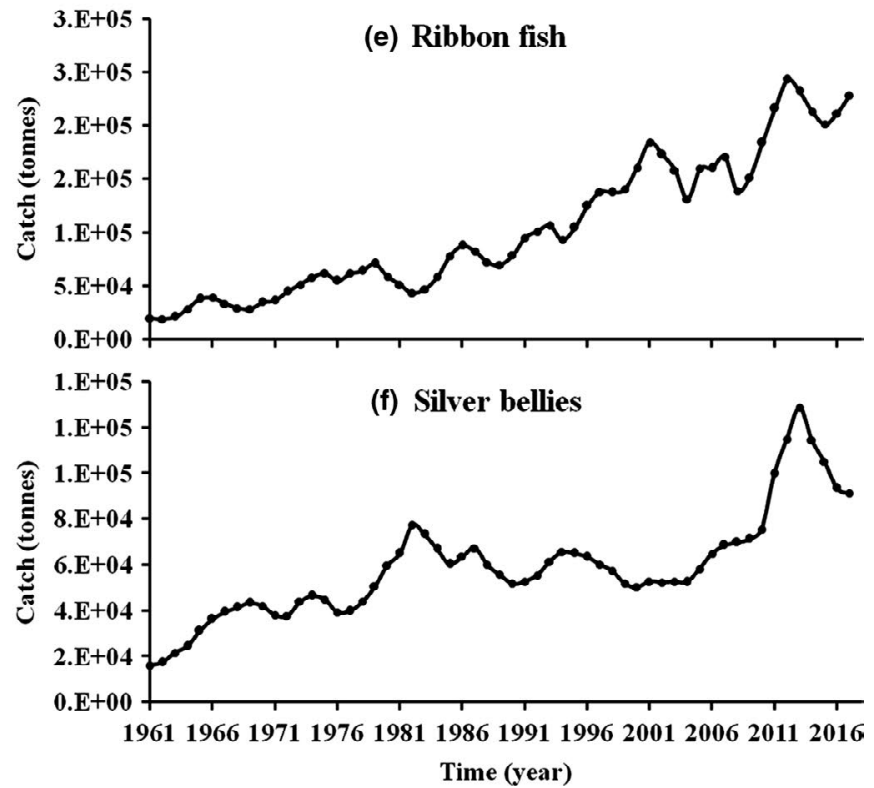

FIG URE 12 Annual times series of catch data (a) Indian oil sardine, (b) Mackerel, (c) Stolephorus, (d) Thryssa, (e) Ribbon fish and (f) Silver bellies for the period of 1961-2017 along the Indian coast

short time interval (Fiedler, 2002; Ma et al., 2019). In general, the present results indicate that the climate indices such as PDO and AMO may influence the landings of oil sardine on a long-term basis and ENSO may have a short-term effect on this species. Thus, a synchrony of these climate forcings in long and short time scales results in the surplus and deficit production of the small pelagic species. However, more study is warranted in this direction to confirm the potential role of PDO and AMO in controlling Indian oil sardine landings in the SEAS coast as well as in other coasts of the Indian peninsula. 


\section{5 | CONCLUSIONS}

The environmental parameters examined in this study, such as salinity, temperature, upwelling index and MLD of the SEAS, suggest that the following mechanism is at work explaining large-scale variability in the landings of Indian oil sardine in the SEAS. The colder temperature and intense upwelling at the right time assure abundant food supply to Indian oil sardine through nutrient enrichment in the surface water promoting the growth of phytoplankton (chl-a). Weaker surface salinity and shoaling of MLD during surplus years could lead to the aggregation of fish at shallow depths resulting in a good catch during fishing operations. The reverse conditions, such as higher surface salinity, warm temperature, downwelling or weak upwelling and thereby lower nutrient concentrations, and deepening of MLD may result in scarce landings during deficit years. These results reveal that environmental parameters play a crucial role in the production of Indian oil sardine in the SEAS. The variability in above environmental parameters has imprints of large-scale climate variability. The Pacific decadal oscillation and Atlantic multidecadal oscillation have pronounced long-term impact than the previously reported ENSO impacts on the landings of Indian oil sardine in the SEAS.

\section{ACKNOWLEDGEMENTS}

Data sets are obtained from http://data.ceda.ac.uk/neodc/esacci, http://www.metoffice.gov.uk/hadobs/en4, http://apdrc.soest.hawaii.edu/data/data.php, https://www.esrl.noaa.gov/psd. Landings data of Indian oil sardine are obtained from annual reports of CMRFI, Kochi, India (http://eprints.cmfri.org.in/). We thank Akash S, Kerala Agricultural University, India for datasets related to standardized catch data of Indian oil sardine (with gear-wise effort). We thank Dr. Nandini Menon, Senior Scientist, NERC-India for the proofreading of the manuscript. We acknowledge the support from MoES through its various programmes operating at IITM.

\section{DATA AVAILABILITY STATEMENT}

The data used for the analysis in the present study are freely available from the following websites http://data.ceda.ac.uk/neodc/esacci, http://www.metoffice.gov.uk/hadobs/en4, http://apdrc.soest. hawaii.edu/data/data.php, https://www.esrl.noaa.gov/psd, http:// eprints.cmfri.org.in/, www.cmfri.org.in/annual-data/

\section{ORCID}

Faseela Hamza iD https://orcid.org/0000-0002-8705-2991

\section{REFERENCES}

Akash, S. (2018). Impact of coastal ocean dynamics on major small pelagic fishery along the west coast of India. B.Sc.-M.Sc. (integrated) climate Change Adaptation thesis. Academy of Climate Change Education and Research, Kerala Agricultural University.

Alder, J., Campbell, B., Karpouzi, V., Kaschner, K., \& Pauly, D. (2008). Forage fish: From ecosystems to markets. Annual Review of Environment and Resources, 33, 153-166. https://doi.org/10.1146/ annurev.environ.33.020807.143204
Alexander, M. A., Kilbourne, K. H., \& Nye, J. A. (2014). Climate variability during warm and cold phases of the Atlantic Multidecadal Oscillation (AMO) 1871-2008. Journal of Marine Systems, 133, 14-26. https:// doi.org/10.1016/j.jmarsys.2013.07.017

Alheit, J., Gröger, J., Licandro, P., McQuinn, I. H., Pohlmann, T., \& Tsikliras, A. C. (2019). What happened in the mid-1990s? The coupled ocean-atmosphere processes behind climate-induced ecosystem changes in the Northeast Atlantic and the Mediterranean. Deep Sea Research Part II: Topical Studies in Oceanography, 159, 130-142. https://doi.org/10.1016/j.dsr2.2018.11.011

Alheit, J., Licandro, P., Coombs, S., Garcia, A., Giráldez, A., Santamaría, M. T. G., \& Tsikliras, A. C. (2014). Reprint of "Atlantic Multidecadal Oscillation (AMO) modulates dynamics of small pelagic fishes and ecosystem regime shifts in the eastern North and Central Atlantic". Journal of Marine Systems, 133, 88-102. https://doi.org/10.1016/j. jmarsys.2014.02.005

Antony Raja, B. T. (1970). Estimation of age and growth of the Indian oil sardine, Sardinella longiceps Val. Indian Journal of Fisheries, 17, 26-42.

Bakun, A., Roy, C., \& Lluch-Cota, S. (1998). Coastal upwelling and other processes regulating ecosystem productivity and fish production in the western Indian Ocean. In K. Sherman, E. Okemwa, \& M. Nitiba (Eds.), Large Marine Ecosystems of the Indian Ocean: Assessment, Sustainability and Management (pp. 103-141). Malden, Massachusetts: Blackwell Sciences Inc.

Bal, D. V., \& Rao, K. V. (1990). Marine fisheries of India. Tata McGraw-Hill Publishing Company Limited.

Barange, M., Coetzee, J., Takasuka, A., Hill, K., Gutierrez, M., Oozeki, Y., van der Lingen, C., \& Agostini, V. (2009). Habitat expansion and contraction in anchovy and sardine populations. Progress in Oceanography, 83, 251-260. https://doi.org/10.1016/j.pocean.2009.07.027

Barange, M., Merino, G., Blanchard, J. L., Scholtens, J., Harle, J., Allison, E. H., Allen, J. I., Holt, J., \& Jennings, S. (2014). Impacts of climate change on marine ecosystem production in societies dependent on fisheries. Nature Climate Change, 4, 211. https://doi.org/10.1038/ NCLIMATE2119

Bensam, P. (1970). On the fluctuations of the oil sardine Fishery at Cannanore during 1961-1964. Indian Journal of Fisheries, 17, 132-148.

Blanchard, J. L., Jennings, S., Holmes, R., Harle, J., Merino, G., Allen, J. I., Holt, J., Dulvy, N. K., \& Barange, M. (2012). Potential consequences of climate change for primary production and fish production in large marine ecosystems. Philosophical Transactions of the Royal Society B: Biological Sciences, 367, 2979-2989. https://doi.org/10.1098/ rstb.2012.0231

Cane, M. A. (2005). The evolution of El Niño, past and future. Earth and Planetary Science Letters, 230, 227-240. https://doi.org/10.1016/j. epsl.2004.12.003

Carton, J. A., Chepurin, G., Cao, X., \& Giese, B. (2000). A simple ocean data assimilation analysis of the global upper ocean 1950-95. Part I: Methodology. Journal of Physical Oceanography, 30, 294-309. https:// doi.org/10.1175/1520-0485(2000)030<0294:ASODAA>2.0.CO;2

Castelao, R. M., \& Barth, J. A. (2006). Upwelling around Cabo Frio, Brazil: The importance of wind stress curl. Geophysical Research Letters, 33, L03602. https://doi.org/10.1029/2005GL025182

Chavez, F. P., Ryan, J., Lluch-Cota, S. E., \& Ñiquen, M. (2003). From anchovies to sardines and back: Multidecadal change in the Pacific Ocean. Science, 299, 217-221. https://doi.org/10.1126/science.1075880

Checkley, D., Alheit, J., Oozeki, Y., \& Roy, C. (2009). Climate change and small pelagic fish. Cambridge University Press. https://doi. org/10.1017/CBO9780511596681

CheckleyJr, D. M., Asch, R. G., \& Rykaczewski, R. R. (2017). Climate, anchovy, and sardine. Annual Review of Marine Science, 9, 469-493. https://doi.org/10.1146/annurev-marine-122414-033819

Cheung, W. W., Lam, V. W., Sarmiento, J. L., Kearney, K., Watson, R. E. G., Zeller, D., \& Pauly, D. (2010). Large-scale redistribution of maximum fisheries catch potential in the global ocean under 
climate change. Global Change Biology, 16, 24-35. https://doi. org/10.1111/j.1365-2486.2009.01995.x

Cheung, W. W., Reygondeau, G., \& Frölicher, T. L. (2016). Large benefits to marine fisheries of meeting the $1.5 \mathrm{C}$ global warming target. Science, 354, 1591-1594. https://doi.org/10.1126/scien ce.aag2331

CMFRI (2018). Annual Report 2017-18. Central Marine Fisheries Research Institute.

Cury, P. M., Boyd, I. L., Bonhommeau, S., Anker-Nilssen, T., Crawford, R. J., Furness, R. W., Mills, J. A., Murphy, E. J., Österblom, H., Paleczny, M., \& Piatt, J. F. (2011). Global seabird response to forage fish depletion-one-third for the birds. Science, 334, 1703-1706. https://doi. org/10.1126/science.1212928

Dee, D. P., Uppala, S. M., Simmons, A. J., Berrisford, P., Poli, P., Kobayashi, S., Andrae, U., Balmaseda, M. A., Balsamo, G., Bauer, D. P., \& Bechtold, P. (2011). The ERA-Interim reanalysis: Configuration and performance of the data assimilation system. Quarterly Journal of the Royal Meteorological Society, 137, 553-597. https://doi. org/10.1002/qj.828

Essington, T. E., Moriarty, P. E., Froehlich, H. E., Hodgson, E. E., Koehn, L. E., Oken, K. L., Siple, M. C., \& Stawitz, C. C. (2015). Fishing amplifies forage fish population collapses. Proceedings of the National Academy of Sciences, 112, 6648-6652. https://doi.org/10.1073/pnas.14220 20112

Ettahiri, O., Berraho, A., Vidy, G., \& Ramdani, M. (2003). Observation on the spawning of Sardina and Sardinella off the south Moroccan Atlantic coast (21-26 N). Fisheries Research, 60, 207-222. https://doi. org/10.1016/S0165-7836(02)00172-8

Fiedler, P. C. (2002). Environmental change in the eastern tropical Pacific Ocean: Review of ENSO and decadal variability. Marine Ecology Progress Series, 244, 265-283. https://doi.org/10.3354/meps244265

Fréon, P., Cury, P., Shannon, L., \& Roy, C. (2005). Sustainable exploitation of small pelagic fish stocks challenged by environmental and ecosystem changes: A review. Bulletin of Marine Science, 76, 385-462.

George, G., Meenakumari, B., Raman, M., Kumar, S., Vethamony, P., Babu, M. T., \& Verlecar, X. (2012). Remotely sensed chlorophyll: A putative trophic link for explaining variability in Indian oil sardine stocks. Journal of Coastal Research, 28, 105-113. https://doi.org/10.2112/ JCOASTRES-D-10-00070.1

Giannoulaki, M., Machias, A., Somarakis, S., \& Tsimenides, N. (2005). The spatial distribution of anchovy and sardine in the northern Aegean Sea in relation to hydrographic regimes. Belgian Journal of Zoology, 135, 151-156.

Gibson-Reinemer, D. K., Ickes, B. S., \& Chick, J. H. (2016). Development and assessment of a new method for combining catch per unit effort data from different fish sampling gears: Multigear mean standardization (MGMS). Canadian Journal of Fisheries and Aquatic Sciences, 74, 8-14. https://doi.org/10.1139/cjfas-2016-0003

Good, S. A., Martin, M. J., \& Rayner, N. A. (2013). EN4: Quality controlled ocean temperature and salinity profiles and monthly objective analyses with uncertainty estimates. Journal of Geophysical Research: Oceans, 118, 6704-6716. https://doi.org/10.1002/2013JC009067

Guiñez, M., Valdés, J., Sifeddine, A., Boussafir, M., \& Dávila, P. M. (2014). Anchovy population and ocean-climatic fluctuations in the Humboldt Current System during the last 700 years and their implications. Palaeogeography, Palaeoclimatology, Palaeoecology, 415, 210-224. https://doi.org/10.1016/j.palaeo.2014.08.026

Harrison, D. E., \& Chiodi, A. M. (2015). Multi-decadal variability and trends in the El Niño-Southern Oscillation and tropical Pacific fisheries implications. Deep Sea Research Part II: Topical Studies in Oceanography, 113, 9-21. https://doi.org/10.1016/j.dsr2.2013.12.020

Haynes, G. M., \& Nichols, J. H. (1994). Pilchard (Sardina pilchardus, Walbaum) egg distribution in the English Channel from plankton surveys in 1978, 1981, 1988 and 1991. Journal of Plankton Research, 16, 771-782. https://doi.org/10.1093/plankt/16.7.771
Hu, Z., Hu, A., \& Hu, Y. (2018). Contributions of Interdecadal Pacific oscillation and Atlantic multidecadal oscillation to Global Ocean heat content distribution. Journal of Climate, 31, 1227-1244. https://doi. org/10.1175/JCLI-D-17-0204.1

Izquierdo-Peña, V., Lluch-Cota, S. E., Hernandez-Rivas, M. E., \& MartínezRincón, R. O. (2019). Revisiting the Regime Problem hypothesis: 25 years later. Deep Sea Research Part II: Topical Studies in Oceanography, 159, 4-10. https://doi.org/10.1016/j.dsr2.2018.11.003

Jayaprakash, A. A. (2002). Long term trends in rainfall, sea level and solar periodicity: A case study for forecast of Malabar sole and Oil sardine fishery. Journal of the Marine Biological Association of India, 44, 163-175.

Jayaprakash, A. A. (2007). Distribution and migration of oil sardine. CMFRI Newsletter.

Joseph, M., \& Jayaprakash, A. A. (2003). Status of exploited marine fishery resources of India. Central MarineFisheries Research Institute.

Jurado-Ruzafa, A., González-Lorenzo, G., Jiménez, S., Sotillo, B., Acosta, C., \& Santamaría, M. T. G. (2019). Seasonal evolution of small pelagic fish landings index in relation to oceanographic variables in the Canary Islands (Spain). Deep Sea Research Part II: Topical Studies in Oceanography, 159, 84-91. https://doi.org/10.1016/j. dsr2.2018.07.002

Kizhakudan, S. J., Raja, S., Gupta, K. S., Vivekanandan, E., Kizhakudan, J. K., Sethi, S. N., \& Geetha, R. (2014). Correlation between changes in sea surface temperature and fish catch along Tamil Nadu coast of India- an indicator of impact of climate change in fisheries. Indian Journal of Fisheries, 61, 111-115.

Knight, J. R., Folland, C. K., \& Scaife, A. A. (2006). Climate impacts of the Atlantic multidecadal oscillation. Geophysical Research Letters, 33, L17706. https://doi.org/10.1029/2006GL026242

Kripa, V., Mohamed, K. S., Koya, K. P., Jeyabaskaran, R., Prema, D., Padua, S., Kuriakose, S., Anilkumar, P. S., Nair, P. G., Ambrose, T. V., \& Dhanya, A. M. (2018). Overfishing and climate drives changes in biology and recruitment of the Indian oil sardine Sardinella longiceps in southeastern Arabian Sea. Frontiers in Marine Science, 5, 443. https:// doi.org/10.3389/fmars.2018.00443

Kripa, V., Prema, D., Jeyabaskaran, R., Khambadkar, L. R., Nandakumar, A., Anilkumar, P. S., Ambrose, T. V., Bose, J., Nair, P. G., \& Pillai, V. N. (2015). Inter-annual variations of selected oceanographic parameters and its relation to fishery of small pelagics off Kochi, southwest coast of India. Journal of the Marine Biological Association of India, 57, 52-57.

Krishnakumar, P. K., \& Bhat, G. S. (2008). Seasonal and interannual variations of oceanographic conditions off Mangalore coast (Karnataka, India) in the Malabar upwelling system during 1995-2004 and their influences on the pelagic fishery. Fisheries Oceanography, 17, 45-60. https://doi.org/10.1111/j.1365-2419.2007.00455.x

Krishnakumar, P. K., Mohamed, K. S., Asokan, P. K., Sathianandan, T. V., Zacharia, P. U., Abdurahiman, K. P., \& Durgekar, N. R. (2008). How environmental parameters influenced fluctuations in oil sardine and mackerel fishery during 1926-2005 along the south-west coast of India? Marine Fisheries Information Service T\&E Ser., 198, 1-5.

Lindegren, M., Checkley, D. M., Rouyer, T., MacCall, A. D., \& Stenseth, N. C. (2013). Climate, fishing, and fluctuations of sardine and anchovy in the California Current. Proceedings of the National Academy of Sciences, 110, 13672-13677. https://doi.org/10.1073/pnas.13057 33110

Lluch-Belda, D. R. J. M., Crawford, R. J., Kawasaki, T., MacCall, A. D., Parrish, R. H., Schwartzlose, R. A., \& Smith, P. E. (1989). World-wide fluctuations of sardine and anchovy stocks: The regime problem. South African Journal of Marine Science, 8, 195-205. https://doi. org/10.2989/02577618909504561

Lluch-Belda, D. A. N. I. E. L., Lluch-Cota, D. B., Hernandez-Vazquez, S. E. R. G. I. O., Salinas-Zavala, C. A., \& Schwartzlose, R. A. (1991). Sardine and anchovy spawning as related to temperature and upwell in the California current system. CalCOFI Reports, 32, 105-111. 
Longhurst, A. (2002). Murphy's law revisited: Longevity as a factor in recruitment to fish populations. Fisheries Research, 56, 125-131. https://doi.org/10.1016/S0165-7836(01)00351-4

Longhurst, A. R., \& Wooster, W. S. (1990). Abundance of oil sardine (Sardinella longiceps) and upwelling on the southwest coast of India. Canadian Journal of Fisheries and Aquatic Sciences, 47, 2407-2419. https://doi.org/10.1139/f90-268

Ma, S., Cheng, J., Li, J., Liu, Y., Wan, R., \& Tian, Y. (2019). Interannual to decadal variability in the catches of small pelagic fishes from China Seas and its responses to climatic regime shifts. Deep Sea Research Part II: Topical Studies in Oceanography, 159, 112-129. https://doi. org/10.1016/j.dsr2.2018.10.005

MacKenzie, B. R., Hinrichsen, H. H., Plikshs, M., Wieland, K., \& Zezera, A. (2000). Quantifying environmental heterogeneity: Habitat size necessary for successful development of cod Gadus morhua eggs in the Baltic Sea. Marine Ecology Progress Series, 193, 143-156. https://doi. org/10.3354/meps193143

Manjusha, U., Jayasankar, J., Remya, R., Ambrose, T. V., \& Vivekanandan, E. (2013). Influence of coastal upwelling on the fishery of small pelagics off Kerala, south-west coast of India. Indian Journal of Fisheries, 60, 37-42.

Mantua, N. J., \& Hare, S. R. (2002). The Pacific decadal oscillation. Journal of Oceanography, 58, 35-44. https://doi.org/10.1023/A:10158 20616384

Menon, N. N., Sankar, S., Smitha, A., George, G., Shalin, S., Sathyendranath, S., \& Platt, T. (2019). Satellite chlorophyll concentration as an aid to understanding the dynamics of Indian oil sardine in the southeastern Arabian Sea. Marine Ecology Progress Series, 617, 137-147. https://doi. org/10.3354/meps12806

Morales-Bojórquez, E., Gómez-Muñoz, V. M., Félix-Uraga, R., \& Alvarado-Castillo, R. (2003). Relation between recruitment, sea surface temperature, and the density-independent mortality of the Pacific sardine (Sardinops caeruleus) off the southwest coast of the Baja California Peninsula, Mexico. Scientia Marina, 67, 25-32. https:// doi.org/10.3989/scimar.2003.67n125

Moyle, P. B., \& Cech, J. J. (2004). Fishes: An introduction to ichthyology, Vol. 726. Upper Saddle River, NJ: Pearson Prentice Hall.

Nair, P. J., Chakraborty, A., Varikoden, H., Francis, P. A., \& Kuttippurath, J. (2018). The local and global climate forcings induced in homogeneity of Indian rainfall. Scientific Reports, 8, 6026. https://doi.org/10.1038/ s41598-018-24021-x

Neelin, J. D., Battisti, D. S., Hirst, A. C., Jin, F. F., Wakata, Y., Yamagata, T., \& Zebiak, S. E. (1998). ENSO theory. Journal of Geophysical Research: Oceans, 103, 14261-14290. https://doi.org/10.1029/97JC03424

Oozeki, Y., Carranza, M. Ñ., Takasuka, A., Dejo, P. A., Kuroda, H., Malagas, J. T., \& Carrasco, R. G. (2019). Synchronous multi-species alternations between the northern Humboldt and Kuroshio current systems. Deep Sea Research Part II: Topical Studies in Oceanography, 159, 11-21. https://doi.org/10.1016/j.dsr2.2018.11.018

Parrish, R. H., Serra, R., \& Grant, W. S. (1989). The monotypic sardines, Sardina and Sardinops: Their taxonomy, distribution, stock structure, and zoogeography. Canadian Journal of Fisheries and Aquatic Sciences, 46, 2019-2036. https://doi.org/10.1139/f89-251

Petitgas, P., Masse, J., Bourriau, P., Beillois, P., Delmas, D., Herbland, A., \& Santos, M. (2006). Hydro-plankton characteristics and their relationship with sardine and anchovy distributions on the French shelf of the Bay of Biscay. Scientia Marina, 70, 161-172. https://doi. org/10.3989/scimar.2006.70s1161

Pikitch, E. K., Rountos, K. J., Essington, T. E., Santora, C., Pauly, D., Watson, R., Sumaila, U. R., Boersma, P. D., Boyd, I. L., Conover, D. O., \& Cury, P. (2014). The global contribution of forage fish to marine fisheries and ecosystems. Fish and Fisheries, 15, 43-64. https://doi. org/10.1111/faf.12004

Rohit, P., Sivadas, M., Abdussamad, E. M., Rathinam, M. M., Said Koya, K. P., Ganga, U., Ghosh, S., Rajesh, K. M., Mohammed Koya, K.
Chellappan, A., Mini, K. G., George, G., Kumar Roul, S., Surya, S., Sukumaran, S., Vivekanandan, E., Retheesh, T. B., Prakasan, D., Satish Kumar, M., ... Supraba, V. (2018). Enigmatic Indian Oil Sardine: An Insight. CMFRI Special publication No. 130, 156.

Rykaczewski, R. R., \& Checkley, D. M. (2008). Influence of ocean winds on the pelagic ecosystem in upwelling regions. Proceedings of the National Academy of Sciences, 105, 1965-1970. https://doi. org/10.1073/pnas.0711777105

Sathyendranath, S., Grant, M., Brewin, R. J. W., Brockmann, C., Brotas, V., Chuprin, A., Doerffer, R., Dowell, M., Farman, A., Groom, S., \& Jackson, T. (2018) ESA Ocean Colour Climate Change Initiative (Ocean_Colour_cci): Version 3.1 Data. Centre for Environmental Data Analysis. http://catalogue.ceda.ac.uk/uuid/9c334fbe6d424a7 08cf3c4cf0c6a53f5

Schwartzlose, R. A., \& Alheit, J. (1999). Worldwide large-scale fluctuations of sardine and anchovy populations. African Journal of Marine Science, 21, 289-347. https://doi.org/10.2989/0257761997 84125962

Silva, A., Santos, M. B., Caneco, B., Pestana, G., Porteiro, C., Carrera, P., \& Stratoudakis, Y. (2006). Temporal and geographic variability of sardine maturity at length in the northeastern Atlantic and the western Mediterranean. ICES Journal of Marine Science, 63, 663-676. https:// doi.org/10.1016/j.icesjms.2006.01.005

Stenseth, N. C., Ottersen, G., Hurrell, J. W., Mysterud, A., Lima, M., Chan, K. S., Yoccoz, N. G., \& Ådlandsvik, B. (2003). Studying climate effects on ecology through the use of climate indices: The North Atlantic Oscillation, El Nino Southern Oscillation and beyond. Proceedings of the Royal Society of London. Series B: Biological Sciences, 270, 2087-2096. https://doi.org/10.1098/ rspb.2003.2415

Stratoudakis, Y., Coombs, S., de Lanzós, A. L., Halliday, N., Costas, G., Caneco, B., \& Bernal, M. (2007). Sardine (Sardina pilchardus) spawning seasonality in European waters of the northeast Atlantic. Marine Biology, 15, 201-212. https://doi.org/10.1007/s00227-007-0674-4

Thompson, D. W., \& Wallace, J. M. (2000). Annular modes in the extratropical circulation. Part I: Month-to-month variability. Journal of Climate, 13, 1000-1016. https://doi.org/10.1175/15200442(2000)013\%3C1000:AMITEC\%3E2.0.CO;2

Trenkel, V. M., Huse, G., MacKenzie, B. R., Alvarez, P., Arrizabalaga, H., Castonguay, M., ... Jacobsen, J. A. (2014). Comparative ecology of widely distributed pelagic fish species in the North Atlantic: Implications for modelling climate and fisheries impacts. Progress in Oceanography, 129, 219-243. https://doi.org/10.1016/j. pocean.2014.04.030

Twatwa, N. M., Van Der Lingen, C. D., Drapeau, L., Moloney, C. L., \& Field, J. G. (2005). Characterising and comparing the spawning habitats of anchovy Engraulis encrasicolus and sardine Sardinops sagax in the southern Benguela upwelling ecosystem. African Journal of Marine Science, 27, 487-499. https://doi.org/10.2989/1814232050 9504107

Uppala, S. M., Kållberg, P. W., Simmons, A. J., Andrae, U., Bechtold, V. D. C., Fiorino, M., Gibson, J. K., Haseler, J., Hernandez, A., Kelly, G. A., \& Li, X. (2005). The ERA-40 re-analysis. Quarterly Journal of the Royal Meteorological Society: A Journal of the Atmospheric Sciences, Applied Meteorology and Physical Oceanography, 131, 2961-3012. https://doi. org/10.1256/qj.04.176

Van der Lingen, C. D., Hutchings, L., Merkle, D., Van der Westhuizen, J. J., \& Nelson, J. (2001). Comparative spawning habitats of anchovy (Engraulis capensis) and sardine (Sardinops sagax) in the southern Benguela upwelling ecosystem. Spatial Processes and Management of Marine Populations, 185-209.

Van Poorten, B., Korman, J., \& Walters, C. (2018). Revisiting BevertonHolt recruitment in the presence of variation in food availability. Reviews in Fish Biology and Fisheries, 28, 607-624. https://doi. org/10.1007/s11160-018-9521-6 
Wilks, D. S. (2011). Statistical methods in the atmospheric sciences (Vol. 100). Academic Press, International Geophysics Series, 684 pp.

Xu, C., \& Boyce, M. S. (2009). Oil sardine (Sardinella longiceps) off the Malabar Coast: Density dependence and environmental effects. Fisheries Oceanography, 18, 359-370. https://doi. org/10.1111/j.1365-2419.2009.00518.x

Zhang, R., \& Delworth, T. L. (2006). Impact of Atlantic multidecadal oscillations on India/Sahel rainfall and Atlantic hurricanes. Geophysical Research Letters, 33, L17712. https://doi.org/10.1029/2006G L026267

Zimmermann, F., Ricard, D., \& Heino, M. (2018). Density regulation in Northeast Atlantic fish populations: Density dependence is stronger in recruitment than in somatic growth. Journal of Animal Ecology, 87, 672-681. https://doi.org/10.1111/1365-2656.12800

Zwolinski, J. P., \& Demer, D. A. (2014). Environmental and parental control of Pacific sardine (Sardinops sagax) recruitment. ICES Journal of Marine Science, 71, 2198-2207. https://doi.org/10.1093/icesjms/ fst173

\section{SUPPORTING INFORMATION}

Additional supporting information may be found online in the Supporting Information section.

How to cite this article: Hamza F, Valsala V, Mallissery A, George G. Climate impacts on the landings of Indian oil sardine over the south-eastern Arabian Sea. Fish Fish.

2021;22:175-193. https://doi.org/10.1111/faf.12513 